\title{
Purinergic signalling links mechanical breath profile and alveolar mechanics with the pro-inflammatory innate immune response causing ventilation-induced lung injury
}

\author{
Djo Hasan $^{1}$ (D) • Paul Blankman ${ }^{1} \cdot$ Gary F. Nieman ${ }^{2}$
}

Received: 13 March 2017 / Accepted: 26 April 2017 /Published online: 26 May 2017

(C) The Author(s) 2017. This article is an open access publication

\begin{abstract}
Severe pulmonary infection or vigorous cyclic deformation of the alveolar epithelial type I (AT I) cells by mechanical ventilation leads to massive extracellular ATP release. High levels of extracellular ATP saturate the ATP hydrolysis enzymes CD39 and CD73 resulting in persistent high ATP levels despite the conversion to adenosine. Above a certain level, extracellular ATP molecules act as danger-associated molecular patterns (DAMPs) and activate the proinflammatory response of the innate immunity through purinergic receptors on the surface of the immune cells. This results in lung tissue inflammation, capillary leakage, interstitial and alveolar oedema and lung injury reducing the production of surfactant by the damaged AT II cells and deactivating the surfactant function by the concomitant extravasated serum proteins through capillary leakage followed by a substantial increase in alveolar surface tension and alveolar collapse. The resulting inhomogeneous ventilation of the lungs is an important mechanism in the development of
\end{abstract}

Electronic supplementary material The online version of this article (doi:10.1007/s11302-017-9564-5) contains supplementary material, which is available to authorized users.

Djo Hasan

djohasan@gmail.com

Paul Blankman

p.blankman@erasmusmc.nl

Gary F. Nieman

niemang@upstate.edu

1 Department of Adult ICU, University Hospital Erasmus MC Rotterdam, 's-Gravendijkwal 2303015 CE, Rotterdam, the Netherlands

2 Department of Surgery, Upstate Medical University, 750 E Adams St, Syracuse, NY 13210, USA ventilation-induced lung injury. The high levels of extracellular ATP and the upregulation of ecto-enzymes and soluble enzymes that hydrolyse ATP to adenosine (CD39 and CD73) increase the extracellular adenosine levels that inhibit the innate and adaptive immune responses rendering the host susceptible to infection by invading microorganisms. Moreover, high levels of extracellular adenosine increase the expression, the production and the activation of profibrotic proteins (such as TGF- $\beta, \alpha$-SMA, etc.) followed by the establishment of lung fibrosis.

Keywords Extracellular ATP · Ventilation-induced lung injury $\cdot$ Diffuse alveolar damage $\cdot$ Purinergic signalling . $\mathrm{CD} 39 \cdot \mathrm{CD} 73$

\section{Introduction}

Diffuse lung injury can be triggered by several experimental conditions, amongst others: Severe pulmonary infection or extrapulmonary infection leads to acute pulmonary distress syndrome (ARDS) [1-5]; Mechanical ventilation with high inspiratory pressures and high tidal volumes of $>30 \mathrm{ml} / \mathrm{kg}$ ideal body weight in animals with healthy lungs causes interstitial and alveolar oedema and diffuse lung injury (ventilation-induced lung injury (VILI)) [6]; And mechanical ventilation in surfactant-deactivated animals causes VILI even with low tidal volume $\left(L V_{\mathrm{T}}\right)$ of $6 \mathrm{ml} / \mathrm{kg}$ [7]. On the other hand, experimental mechanical ventilation with airway pressure release ventilation (APRV) with relatively long inspiration time and very short pressure release period may protect the lungs [7-14].

It is clear that lung infection results in pro-inflammatory immune response. In addition, there is a general agreement that ventilation of inhomogeneous lung tissue and/or with a 
high tidal volume triggers a pro-inflammatory response [15-19]. The corollary to this is that reduction of tidal volume and return to homogeneous ventilation will reduce (but not prevent) this pro-inflammatory response [19]. However, the exact mechanism of ventilation-induced pro-inflammatory response that leads to VILI is still not fully understood [15-18]. Moreover, the combination of all mechanical breath parameters (known as the mechanical breath profile (MBP) airway pressures, volumes, flow rates and the duration at both inspiration and expiration) applied with each breath, which injure or protect the lung, is still not known.

In this review, we have searched the literature thoroughly to identify the (missing) link between the MBP, alveolar mechanics (i.e. the dynamic change in alveolar size and shape during tidal ventilation) and the inflammatory response that causes VILI.

\section{Alveolar mechanics, alveolar surface tension and VILI}

Conventional mechanical ventilator settings consist of a static and a dynamic component. The static component is a continuous pressure or stress applied during both the inspiration and expiration and results in a static volume change or static strain. Strain is defined as a change in volume normalised by the original volume. The static stress and strain are referred to as positive end-expiratory pressure (PEEP) and the change in end-expiratory lung volume (EELV) normalised by the functional residual capacity (FRC) of the lungs, respectively. If the applied PEEP is zero, the EELV equals the FRC. Thus, EELV equals FRC plus PEEP volume. The dynamic component is the strain (i.e. tidal volume $\left(V_{\mathrm{T}}\right)$ normalised by FRC or EELV) inflicted by the cyclic stress, i.e. the inspiratory pressure [20].

\section{Cyclic lung volume change with high energy load causes VILI in healthy lungs}

Protti et al. determined the mean value of the global energy load calculated from the mean inspiratory capacity by means of whole-lung CT scan in 76 pigs with healthy lungs [6]. Mean inspiratory capacity was defined as the mean value of total lung capacity (TLC) measured at $45 \mathrm{~cm} \mathrm{H}_{2} \mathrm{O}$ airway pressure minus the FRC measured at $0 \mathrm{~cm} \mathrm{H}_{2} \mathrm{O}$ airway pressure. The global energy load during conventional mechanical ventilation comprised a static component due to lung volume caused by the applied PEEP and a dynamic component due to the applied inspiratory pressure. The lower and upper limit of the applied global energy load was set at the value of mean global energy load $\pm 2 \mathrm{SD}$ (equivalent to an inspiratory capacity range of $30.9-59.7 \mathrm{ml} / \mathrm{kg}$ ideal bodyweight). Then, the animals were subjected to different levels of PEEP and inspiratory pressures. When the mean global energy load did not exceed its lower limit, lung damage was not observed and only 1 of the 29 experimental animals did not survive the experiment. In contrast, when the mean global energy load exceeded the lower limit of the global energy load, lung injury, pro-inflammatory cytokine production and death were observed in 26 of the 47 experimental animals. In these cases, lung damage was associated with high dynamic energy load rather than high static energy load [6]. In addition, the rate of the applied strain was associated with ventilation-induced lung oedema and lung injury [21].

\section{In surfactant-deactivated lungs cyclic lung volume change causes VILI even with low energy load}

Remarkably, the threshold of the energy load above which lung damage occurred in healthy pig lungs was quite high (equivalent to a mean $V_{\mathrm{T}}$ of $>30 \mathrm{ml} / \mathrm{kg}$ ideal body weight) [6], whereas a $V_{\mathrm{T}}$ of $6 \mathrm{ml} / \mathrm{kg}$ is already injurious in the surfactant-deactivated lungs [11]. This difference is clearly illustrated in the following experiment. In anaesthetised mechanically ventilated pigs, normal subpleural alveoli were filmed in real time using in vivo video microscopy. This study discovered that there was very little change in alveolar size in healthy lungs when ventilated with $L V_{\mathrm{T}}(6 \mathrm{ml} / \mathrm{kg}$ ideal body weight) or with $H V_{\mathrm{T}}$ (12 or $15 \mathrm{ml} / \mathrm{kg}$ ideal body weight). In contrast, after surfactant deactivation with a detergent as a model of ARDS, the alveoli became unstable: Many alveoli collapsed at the end of the expiration, and some of these collapsed alveoli were recruited during inspiration irrespective of the magnitude of the tidal volume. Alveoli that remained open at the end of the expiration became over-distended during the inspiration resulting in an inhomogeneous ventilation pattern in the lungs [22].

\section{Stabilization of the alveoli prevents VILI}

Bachofen and Schürch demonstrated with scanning electron micrographs that surfactant deactivation and consequently increased surface tension in the alveoli in detergent rinsed lungs increase the alveolar duct surface area at the expense of alveolar surface area as compared to normal lungs. The increased alveolar duct size is accompanied by a decrease in the alveolar diameter perpendicular to the axis of the alveolar ducts (alveolar wall compression) and by an increase in the alveolar diameter parallel to the axis of the alveolar ducts. Therefore, surfactant deactivation is accompanied by alveolar wall stretching [23]. This finding was confirmed in an experiment in anaesthetised rats by the group of Nieman. After en bloc excision of the lungs, one of the lungs was clamped and fixed in formalin at peak inspiration pressure and the other at end expiration pressure for histologic analysis. In this way, they were able to visualise the effect of surfactant deactivation (Tween-induced ARDS model) and mechanical ventilator 
Fig. 1 Photomicrographs of rat lungs. After en bloc excision of the lungs, one of the lungs was clamped and fixed in formalin at peak inspiration pressure and the other at end expiration pressure for histologic analysis. The respiratory bronchiole, alveolar ducts and alveolar sacs are green; the alveoli are lilac; and the alveolar walls are magenta. Healthy lungs ventilated with controlled continuous mandatory ventilation (CMV) with low tidal volume ( $\leq 6 \mathrm{ml} / \mathrm{kg}$ ideal body weight) and $5 \mathrm{~cm} \mathrm{H}_{2} \mathrm{O}$ PEEP (control). APRV: surfactant-deactivated lungs with intratracheal instillation of a detergent ventilated with $T_{\text {low }}$ being interrupted when the endexpiratory flow (EEF) reached $75 \%$ (APRV 75\%) or 10\% (APRV 10\%) of the peak expiratory flow (PEF). (PEEP 5) Surfactant-deactivated lungs ventilated with the same settings as 'control' or with PEEP $16 \mathrm{~cm} \mathrm{H}_{2} \mathrm{O}$ (PEEP 16) (see Table 1 for the mechanical breath profile data). Note that the highest alveolar duct surface area is reached during inspiration in APRV $10 \%$ followed by PEEP 5; the lowest alveolar duct surface area is observed in the control group. The highest alveolar stability (the smallest difference in alveolar duct surface area between inspiration and expiration) with the lowest microstrain is reached in healthy lungs (control) followed by APRV 75\%. The lowest alveolar stability and the highest microstrain are seen in APRV $10 \%$ and PEEP 5. Microstrain is calculated as the change in length of the alveolar ducts between inspiration and expiration normalised by their original length. The difference between the control group and PEEP 5 is exclusively attributed to the surfactant function. APRV can either significantly increase (APRV 10\%) or decrease (APRV 75\%) the microstrain and the redistribution of air towards the alveolar ducts. Figure from Kollisch-Singule et al. [8] with permission

settings on alveolar duct microstrain and the distribution of inspired air between the alveolar ducts and the alveoli (Fig. 1) [8]. Microstrain was calculated as the change in length of the alveolar ducts between inspiration and expiration normalised by their original length. As the increase in the alveolar duct size after surfactant deactivation is accompanied by alveolar wall stretching parallel to the axis of the alveolar ducts [23], alveolar duct microstrain is likely to be proportional to the alveolar wall stretching and alveolar wall strain.

Four ventilation strategies were tested by this group [8]: $L V_{\mathrm{T}}$ plus two levels of PEEP ( 5 and $16 \mathrm{~cm} \mathrm{H}_{2} \mathrm{O}$ ) and APRV with the expiratory termination set at either an end-expiratory flow (EEF) of $10 \%$ (APRV 10\%) of the peak-expiratory flow (PEF) or an EEF of 75\% of the PEF (APRV 75\%) [24, 25]; the higher the EEF/PEF ratio (i.e. $75 \%$ as compared with $10 \%$ ), the shorter the expiratory duration (see Table 1 for the MBP of the set ventilator modes). Previous studies have shown that APRV 75\% stabilises alveoli preventing alveolar collapse during expiration, whereas an APRV $10 \%$ extends the duration of expiration resulting in alveolar collapse [12, 24, 25]. This study demonstrated that APRV 10\% caused high microstrain and redistribution of air towards the alveolar ducts as compared with APRV 75\%, which resulted in almost normal distribution of air (Fig. 1). The order of ventilation strategies that caused the most to the least redistribution of inspired air into alveolar ducts (inspiratory ratio $C_{\mathrm{a}} / A_{\mathrm{a}}$ in Table 2) and microstrain was as follows: APRV 10\%, PEEP 5, PEEP 16, APRV 75\% and control (Table 2). Obviously, the least injurious ventilator settings are those that mimic the microstrain and air redistribution levels in ventilated healthy lungs with intact

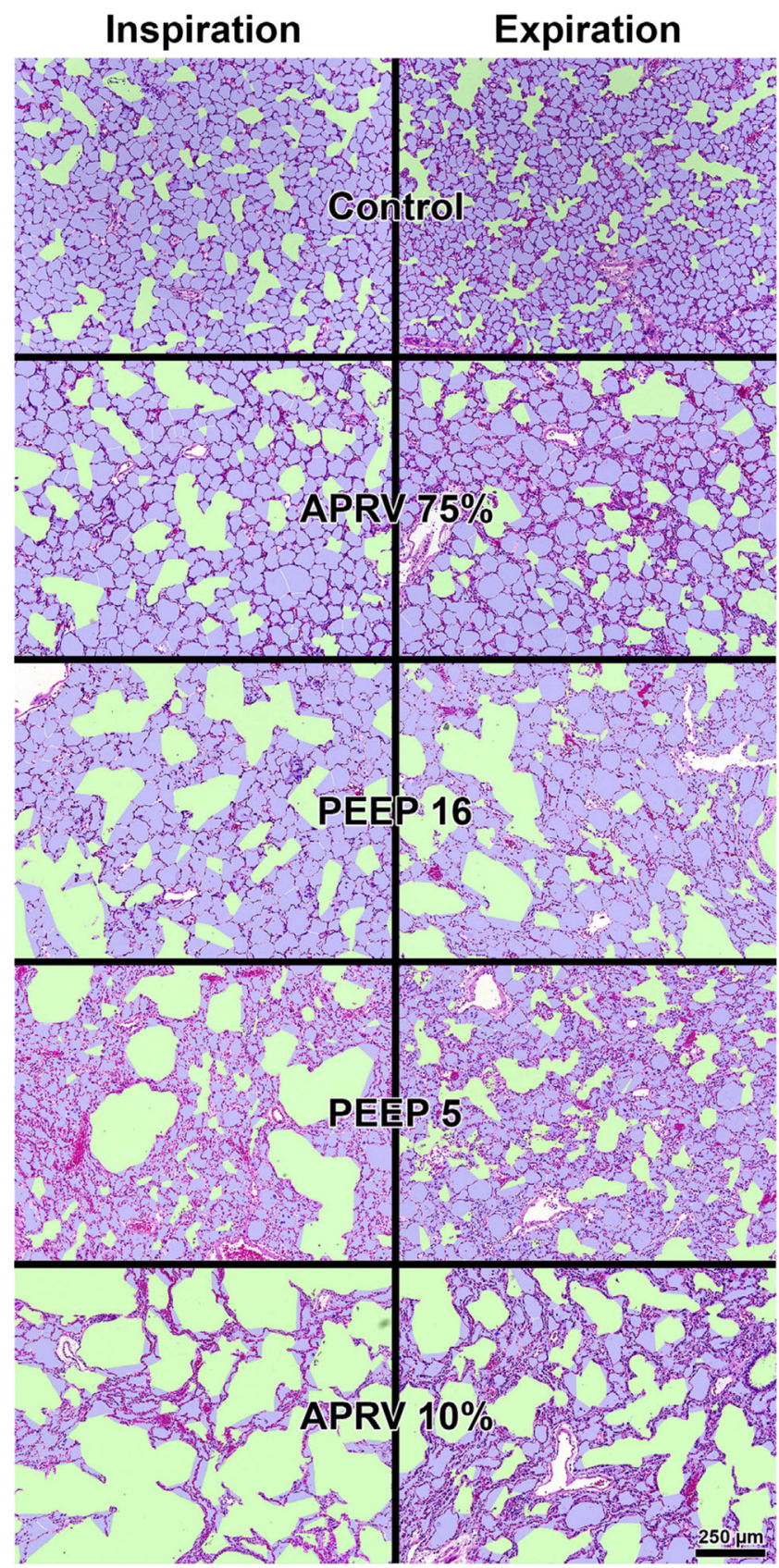

surfactant function (control in Fig. 1). APRV 75\% resulted in near normal microstrain and alveolar air distribution, which was very similar to that measured in normal lungs, even though APRV $75 \%$ was in a Tween-induced ARDS model (Fig. 1, APRV 75\% and Table 2). In this high surface tension ARDS model, the lower the PEEP (PEEP 5 vs PEEP 16) and the longer the expiratory duration ( $10 \mathrm{vs} 75 \%$ ), the worse the microstrain and alveolar air distribution (Fig. 1, Table 2). This research group hypothesised that the mechanism by which APRV $75 \%$ was so effective at normalizing microstrain and alveolar air distribution was as follows: The extended time at inspiration (achieved by applying continuous positive airway 
Table 1 Mechanical breath profile (MBP) of the set ventilator modes

\begin{tabular}{lccccc}
\hline MBP & \multicolumn{2}{l}{ Ventilator mode } & & \\
\cline { 2 - 6 } & Control $^{\mathrm{a}}$ & APRV 75\% & PEEP 16 & PEEP 5 & APRV 10\% \\
\hline Plateau pressure $\left(\mathrm{cm} \mathrm{H}_{2} \mathrm{O}\right)$ & $\mathrm{N} / \mathrm{A}$ & 36.7 & 31 & 22.8 & 36.7 \\
Tidal volume $(\mathrm{ml} / \mathrm{kg})$ & 6 & 10.9 & 5.68 & 5.34 & 17 \\
PEEP $\left(\mathrm{cm} \mathrm{H}_{2} \mathrm{O}\right)$ & 5 & $\mathrm{~N} / \mathrm{A}$ & 16 & 5 & $\mathrm{~N} / \mathrm{A}$ \\
Respiratory frequency $\left(\mathrm{min}^{-1}\right)$ & 55 & 29.2 & 55 & 55 & 26.9 \\
Inspiratory time or $T_{\text {high }}(\mathrm{s})$ & 0.73 & $1.9-2.0$ & 0.73 & 0.73 & $1.9-2.0$ \\
Expiratory time or $T_{\text {low }}(\mathrm{s})$ & 0.36 & $0.04-0.08$ & 0.36 & 0.36 & $0.22-0.26$ \\
\hline
\end{tabular}

The columns are sorted according to increasing microstrain values as shown in Table 2. APRV: $T_{\text {low }}$ being interrupted when the end-expiration flow (EEF) reached 75\% (APRV 75\%) or 10\% (APRV 10\%) of the peak expiratory flow (PEF)

${ }^{a}$ The values in the control column are set values of the mechanical ventilator. The values in columns of the remaining ventilator modes are measured MBP values [12] pressure) recruited almost all alveoli, and the very short time at expiration prevented these newly recruited alveoli from collapsing. In contrast, APRV 10\% resulted in the worst microstrain and air distribution since the high pressure and extended inspiratory duration opened alveoli but the excessively long expiratory duration allowed time for all of the newly opened alveoli to collapse (Fig. 1) [8]. One mechanism of this lung protection was that APRV 75\% preserved surfactant function, measured by increased concentrations of surfactant protein-A (SP-A) and SP-B in the bronchoalveolar lavage fluid, as compared to controlled CMV with a $V_{\mathrm{T}}$ of $10 \mathrm{ml} / \mathrm{kg}$ ideal body weight [10]. Apparently, redistribution of air towards the alveolar ducts and the increase in microstrain in controlled CMV deplete pulmonary surfactant. This supports earlier works showing that mechanical ventilation can impair pulmonary surfactant function $[26,27]$.

The protective effect of APRV 75\% (APRV settings: $P_{\text {high }}$ 16-22 $\mathrm{cm} \mathrm{H}_{2} \mathrm{O}, T_{\text {high }} 4.5 \mathrm{~s}, P_{\text {low }} 0 \mathrm{~cm} \mathrm{H}_{2} \mathrm{O}$ ) on lung tissue injury was also demonstrated in anaesthetised pigs with extrapulmonary ARDS. In contrast to $L V_{\mathrm{T}}$ controlled CMV
$\left(V_{\mathrm{T}} 6 \mathrm{ml} / \mathrm{kg}\right.$ ideal body weight, RR 55/min, I/E 1:2, $\mathrm{FiO}_{2}$ $21 \%$ PEEP $5 \mathrm{~cm} \mathrm{H}_{2} \mathrm{O}$ and guided by the ARDSnet protocol [28]), APRV 75\% was capable of preventing the development of DAD while maintaining lung elastance low, despite the fact that APRV 75\% generated similar transpulmonary pressure compared to $L V_{\mathrm{T}}$ [11].

\section{The characteristics of lung tissue damage in ARDS and VILI are pointing at the activation of the innate immune system}

The histopathology of VILI is referred to as diffuse alveolar damage (DAD) and is very similar to the histopathology associated with experimental ARDS. Reportedly, in contrast to the animal models of ARDS [29, 30], histopathology of DAD is found in only one third to half of patients with clinical diagnosis of ARDS [31-33]. ARDS is caused by multiple primary disease conditions such as sepsis, haemorrhagic shock and pneumonia, and these patients will require
Table 2 Microstrain and redistribution of the inspired air from the alveoli towards the alveolar ducts (ratio $C_{\mathrm{a}} / A_{\mathrm{a}}$ )

\begin{tabular}{llllll}
\hline Effects of MBP on the lung tissue & \multicolumn{2}{l}{ Ventilatory mode } \\
\cline { 2 - 6 } & Control & APRV 75\% & PEEP 16 & PEEP 5 & APRV 10\% \\
\hline Microstrain & 0.137 & 0.202 & 0.231 & 0.336 & 0.394 \\
Ratio $C_{\mathrm{a}} / A_{\mathrm{a}}$ (inspiration) & 0.33 & 0.65 & 0.81 & $0.9 *$ & $2.07^{*}$ \\
Ratio $C_{\mathrm{a}} / A_{\mathrm{a}}$ (expiration) & 0.35 & 0.51 & $0.79^{*}$ & 0.6 & $1.32^{*}$ \\
\hline
\end{tabular}

The columns are sorted according to increasing microstrain values. Microstrain is calculated as the change in length of the alveolar ducts between inspiration and expiration normalised by their original length. The lowest microstrain is observed in the control group and increasing in APRV 75\%, PEEP 16, PEEP 5 and APRV 10\%, respectively. Table based on Table 2 in the article by Kollisch-Singule, et al. 2014 [8] with permission

$C_{\mathrm{a}}$ alveolar duct surface area, $A_{\mathrm{a}}$ alveolar surface area, APRV $10 \%$ the expiratory termination set at an endexpiratory flow (EEF) of $10 \%$ of the of the peak expiratory flow (PEF), APRV $75 \%$ the expiratory termination set at an EEF of $75 \%$ of the PEF

$* p<0.05$ vs control 
mechanical ventilation. If set improperly, mechanical ventilation can cause a secondary VILI, which will aggravate the DAD caused by the primary disease. There are three distinctive stages in the histopathology of DAD $[34,35]$ : The early exudative stage initiates after 12 to $24 \mathrm{~h}$ with declining frequency to almost zero after 4 weeks, the late proliferative stage with increasing frequency reaching almost $100 \%$ after 4 weeks and the fibrotic stage after 1 week increasing gradually reaching about $60 \%$ after 4 weeks. In the first 12 to $24 \mathrm{~h}$ : capillary congestion, interstitial and alveolar oedema [34]. The oedema results mainly from capillary leakage of fluid and proteins [36]. After $24 \mathrm{~h}$, the characteristic histopathology is the presence of hyaline membranes. These membranes are found adjacent to the alveolar ducts and alveolar walls consisting of eosinophilic structures with cell debris, plasma proteins and surfactant degradation products. The alveolar walls are oedematous and thickened and filled with myxoid matrix comprising fibroblasts and myofibroblasts (fibroblasts phenotype containing alpha smooth muscle actins ( $\alpha$-SMA)), slight infiltration of the interstitial space with lymphocytes, plasma cells and macrophages. A significant proportion of the alveolar epithelial type I (AT I) cells and a small proportion of the AT II cells are damaged and lost leaving the alveolar membranes exposed. This means that the physical barrier against pathogens - a component of the innate immunity - is disrupted. Self-renewal of the epithelium (AT I and AT II cells) is performed by the AT II cells [37] and is accompanied by AT II hyperplasia which appears in 3 to 6 days. Mild endothelial injury is also reported [34]. In the proliferative phase of DAD, hyaline membranes are no longer prominent. The characteristic histopathology in the interstitium is the proliferation of fibroblasts, myofibroblasts and AT II cells mixed with occasional inflammatory cells. This granulation tissue breaks through the basement membrane into the alveolar spaces. The proliferating AT II cells show metaplasia resembling squamous cell carcinoma [34]. These AT II cells migrate over the surface of the alveolar granulation tissue and the intraalveolar exudate establishing the so-called fibrosis by accretion [38]. In addition, fibrosis is also formed by collagen deposits in the process of the organization of the interstitial oedema [34]. These processes and the increase in the surface tension by the deficient surfactant production and function in the inflammatory process lead to the collapse of the alveoli, size reduction of the remaining open alveoli and dilated alveolar ducts [23, 38]. After 3 to 4 weeks, granulation tissue of the fibrotic process dominates the lung histology. Enlarged airspaces - most likely in the alveolar ducts $[8,23,38]$ - are outlined by collapsed alveoli with thickened alveolar walls [34]. The percentage of fibrosis and the amount of interstitial tissue increase over time [39]. In addition, the normally nonmuscular small arteries are being muscularised and muscular arteries show intimal and subintimal fibrous thickening. This development may end in pulmonary hypertension [34].

\section{Surfactant metabolism and physiological purinergic signalling in the lungs are required for the release of surfactant by the AT II cells}

Since surfactant dysfunction plays a crucial role in the development of DAD, the regulation of metabolism and secretion of surfactant may contribute to the pathogenesis of DAD.

Surfactant lipids and surfactant proteins are synthetised through different pathways by the AT II cells in the alveolar walls. Surfactant protein (SP-A, SP-B, SP-C and SP-D) synthesis starts in the endoplasmic reticulum (ER). The surfactant protein molecules are transported from the ER to the Golgi complex. SP-A and SP-D are excreted directly to the extracellular space [40]. SP-A and SP-D (both are hydrophilic protein molecules) belong to the collectins, a family of calciumdependent sugar-binding proteins (lectins) containing collagen-like sequences and carbohydrate recognition domains (CRDs). Collectins are soluble pattern recognition receptors (PRRs, components of the innate immunity) that can identify pathogen-associated molecular patterns (PAMPs) and several danger-associated molecular patterns (DAMPs) [41, 42]. SP-B and SP-C plus ATP-binding cassette subfamily A member 3 (ABCA3, a surfactant lipid transporter) are transported from the Golgi complex to the multivesicular bodies (MVBs). Fusion of MVBs and the lamellar bodies (LBs) leads to the proteolytic process of SP-B and SP-C to the mature form. The surfactant lipids are produced in the ER as well but transported directly to the LBs by means of the lipid transporter ABCA3. The hydrophobic proteins SP-B and SP-C are essential in the packing process of surfactant lipid molecules in the LBs [40].

Under physiological conditions, mammalian cells contain high concentrations of ATP ( 5 to $8 \mathrm{mM}$ ) and ADP [43]. In the extracellular space, ATP can be detected in much lower (nanomolar) concentrations around resting cells [44]. Certain conditions may cause the release of ATP. In cell stress conditions such as an infection, ATP can be released in a controlled manner through pannexin hemichannels (mainly Panx1) [45, 46], connexin channels (mainly $\mathrm{Cx} 43$ ) [47, 48], certain chloride channels (maxi-anion channels, volume-regulated anion channels (VRAC), cystic fibrosis transmembrane conductance regulator (CFTR), chloride channel $(\mathrm{ClC})$ family and calcium-activated chloride channel (CACC)) [49] and P2X7 ATP receptors (P2X7Rs) [50, 51] to $>1000$-fold of the resting state levels to micromolar concentrations. In cell ischemia and cell necrosis, ATP is released massively and uncontrolled [43, 52, 53]. Infection (such as in ARDS due to infectious agents) induces the release of extracellular ATP by many inflammatory cells and tissue cells (such as the AT I cells) [43, 52, 53]. In non-infectious circumstances such as physiological mechanical deformation (stretch or compression during breathing or mechanical ventilation) of the AT I cells stimulates the P2X7Rs followed by the controlled release of ATP molecules 
through the P2X7R channel into the extracellular space (Fig. 2) [54, 57].

Recently, using real-time luciferin-luciferase bioluminescence imaging coupled with simultaneous infrared differential interference contrast imaging, Furuya et al. were able to produce real-time imaging of inflation-induced ATP release in the ex vivo rat lung. They observed that lung inflation induces ATP release into alveolar spaces and into pulmonary blood capillaries [58]. In this way, extracellular purine nucleotides (such as ATP) play the key role in the extracellular signalling (purinergic signalling) of many biological processes and can activate purinergic receptors - for example, the $\mathrm{P} 2 \mathrm{Y} 2 \mathrm{R}$ - on the cell membranes [52]. The extracellular ATP originating from the AT I cells, released through the P2X7Rs by mechanical deformation, activates the P2Y2Rs on the surface of the AT II cells. The P2Y2R is a metabotropic G protein-coupled ATP receptor (GPCR). Activation of the P2Y2R by ATP results in the release of diacylglycerol (DAG) and inositol triphosphate $\left(\mathrm{IP}_{3}\right)$ into the cytoplasm. DAG activates the enzyme protein kinase $\mathrm{C}$ (PKC) that promotes the fusion of LBs with the cell membrane (Fig. 2). Cytoplasmic $\mathrm{IP}_{3}$ results in the release of intracellular $\mathrm{Ca}^{2+}$ by stores that are sensitive to $\mathrm{IP}_{3}$ and $\mathrm{Ca}^{2+}$ entry from the extracellular space through several pathways (TRPV2 and STIM1/Orai1). The increased cytoplasmic $\mathrm{Ca}^{2+}$ level also promotes the fusion of the LBs with the cell membrane of the AT II cells and creates a fusion

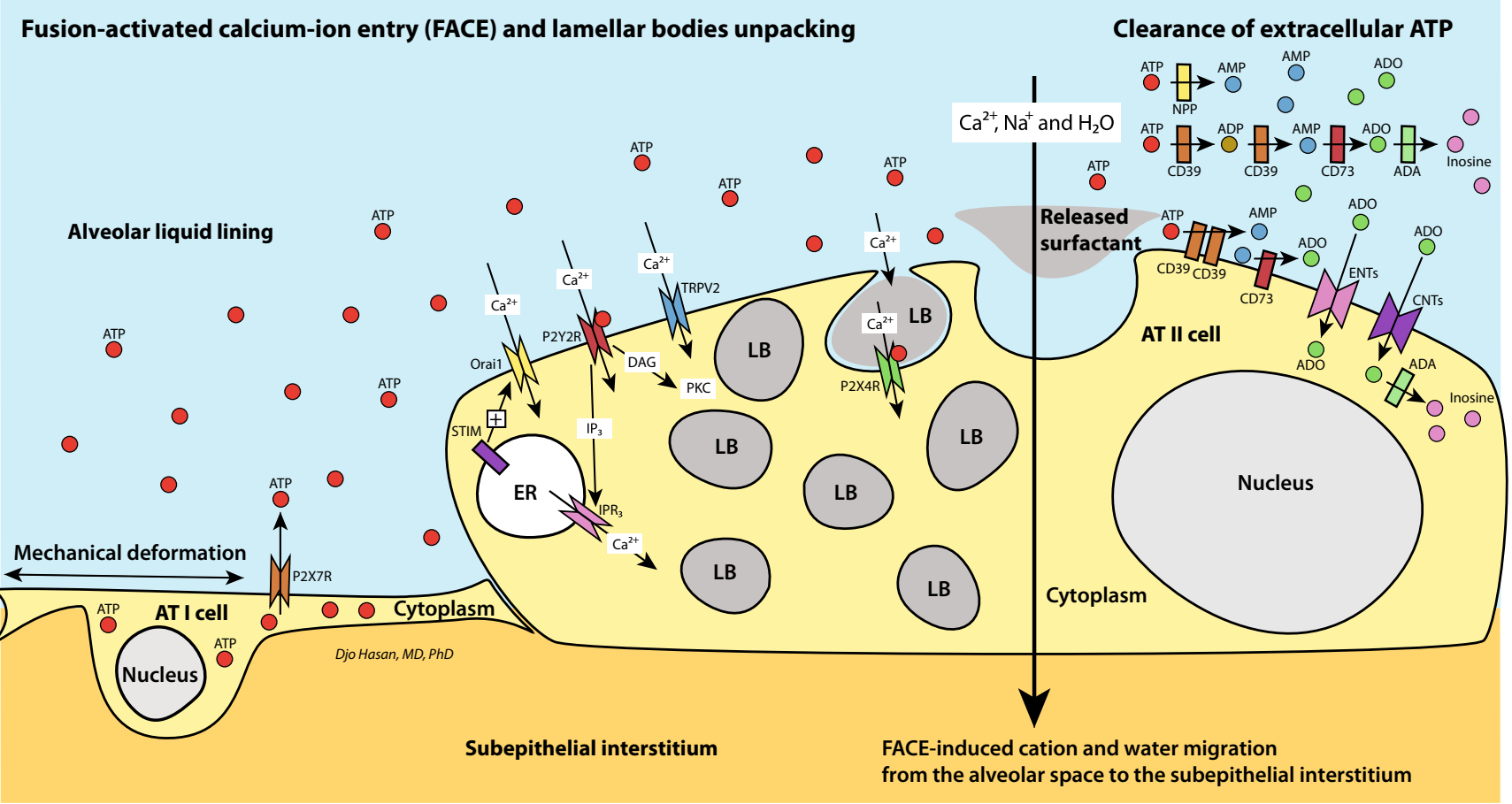

Fig. 2 Schematic presentation of the fusion-activated $\mathrm{Ca}^{2+}$ entry (FACE). AT I cells release ATP to the extracellular space through the P2X7R (ATP receptor that can function as an ATP channel) provoked by mechanical deformation (compression or stretching) [43, 54-56]. The extracellular ATP activates the P2Y2Rs on the surface of the AT II cells in a paracrine manner. The $G$ protein-coupled P2Y2 ATP receptor releases DAG and $\mathrm{IP}_{3}$ into the cytoplasm. DAG release leads to the activation of PKC-dependent pathway of fusion of LBs with the cell membrane. $\mathrm{IP}_{3}$ release results in the release of intracellular $\mathrm{Ca}^{2+}$ by stores that are sensitive to $\mathrm{IP}_{3}$ and $\mathrm{Ca}^{2+}$ entry from the extracellular space through several pathways (TRPV2 and STIM1/Orai1). Increased cytoplasmic $\mathrm{Ca}^{2+}$ level also promotes the fusion of the LBs with the cell membrane of the AT II cells. These two processes create a fusion pore causing the P2X4 ATP receptors in the membrane of the LBs to be exposed to extracellular ATP. Activation of these P2X4Rs by extracellular ATP strongly increases the local $\mathrm{Ca}^{2+}$ concentration to a much higher level around the membrane of the fused vesicles (FACE). FACE promotes a significant expansion of the fusion pore resulting in surfactant release by the AT II cells (LBs unpacking) and is accompanied by the FACE-induced cations and water migration from the alveolar space to the subepithelial interstitium. Clearance of the ATP molecules from the extracellular space occurs through the stepwise conversion by ecto-enzymes or by soluble extracellular enzymes (CD39 and CD73) to adenosine (ADO). ADO is returned to the cytoplasm through ENTs or CNTs and converted by ADA to inosine in the cytoplasm or converted by soluble ADA in the extracellular space. AT I alveolar epithelial type I cell, AT II alveolar epithelial type II cell, $E R$ endoplasmic reticulum, $L B$ lamellar body, $D A G$ diacylglycerol, $P K C$ protein kinase $\mathrm{C}, I P_{3}$ inositol triphosphate, $I P_{3} R$ inositol triphosphate receptor, a membrane bound glycoprotein complex functioning as a $\mathrm{Ca}^{2+}$ channel sensitive to activation by inositol triphosphate, TRPV2 transient receptor potential cation channel subfamily $\mathrm{V}$ member 2, a nonselective cation channel, STIM1 stromal interaction molecule 1, a calcium sensor, Orail calcium release-activated calcium channel protein 1, a calcium selective ion channel, CD39 nucleoside triphosphate diphosphohydrolase 1 (NTPD1), NPP nucleotide pyrophosphatase/phosphodiesterase, $C D 73$ 5'-nucleotidase (5'-NT), $A D A$ adenosine deaminase, ENTS equilibrative nucleoside transporters 1 and 2, CNTS concentrative nucleoside transporters 1 and 2 
pore causing the P2X4Rs in the membrane of the LBs to be exposed to the extracellular ATP (Fig. 2). Activation of these P2X4Rs by extracellular ATP strongly increases the local $\mathrm{Ca}^{2+}$ concentration around the membrane of the fused vesicles to a much higher level (Fig. 2). This process-referred to as 'fusion-activated' $\mathrm{Ca}^{2+}$ entry (FACE) - promotes a significant expansion of the fusion pore resulting in surfactant release by the AT II cells (LBs unpacking). Thus, the AT I cells induce the unpacking of LBs by the AT II cells in a paracrine manner (Fig. 2) [54, $55,59,60]$. In addition, at a higher degree of stretch of the AT II in vitro (probably comparable to a deep sigh), ATP molecules can be released to the extracellular space and induce LBs unpacking in an autocrine manner [57].

FACE drives a trans-epithelial current of $\mathrm{Na}^{+}$and $\mathrm{Ca}^{2+}$ from the alveolar lumen through the P2X4R in the fused LB membranes and the cytoplasm to the subepithelial interstitium. This is followed by a passive water resorption from the alveolar space to the subepithelial interstitial space. In other words, extracellular ATP induces extracellular excretion of surfactant to the alveolar space and reduces the quantity of fluid in the alveolar liquid lining maximizing the reduction of the surface tension of the alveoli (Fig. 2) [56].

The P2X7Rs that release the extracellular ATP molecules are not subject to a refractory period during mechanical deformation [57]. In rat glomerular mesangial cell culture, $72 \%$ of the cells show an increase in $\mathrm{Ca}^{2+}$ levels during a 2-min stimulus with $100 \mu \mathrm{M}$ ATP through the P2Y2Rs. In contrast to the p2X7Rs, the P2Y2Rs start to desensitise within $1 \mathrm{~min}$, and the sensitivity to stimuli reaches its minimum within 2 to $4 \mathrm{~min}$ $[61,62]$. After a recovery period of another $4 \mathrm{~min}$, only $38 \%$ of the cells respond to a second stimulus. The response following the second stimulus is much weaker than the first stimulus [62]. The P2X4Rs become desensitised faster than the P2Y2Rs (within a few seconds after a stimulus with ATP), and the sensitivity to stimuli reaches its minimum after 30 to $60 \mathrm{~s}$ [63, 64]. Therefore, vigorous mechanical deformation of the AT I cells may cause excessive extracellular release of ATP but is unlikely to cause massive LBs unpacking.

Clearance of the ATP and ADP molecules from the extracellular space is performed through the stepwise conversion of extracellular ATP molecules by ecto-enzymes or by soluble extracellular enzymes to adenosine (Fig. 2). These enzymes comprise nucleoside triphosphate diphosphohydrolase 1 (NTPD1 or CD39, conversion of ATP to ADP and ADP to AMP), nucleotide pyrophosphatase/phosphodiesterase (NPP, conversion of ATP to AMP) and 5'-nucleotidase (5'-NT or CD73, conversion of AMP to adenosine). Then, adenosine is converted by soluble extracellular adenosine deaminase (ADA) to inosine or is returned to the cytoplasm of the cells through the equilibrative nucleoside transporters (ENT1 and ENT2) and concentrative nucleoside transporters (CNT1 and CNT2). Inside the cells, adenosine is being further processed by ADA and purine nucleoside phosphorylase (PNP) to inosine and hypoxanthine, respectively, and by adenosine kinase (ADK) to AMP [43, 52, 53, 65]. Under normal conditions, extracellular levels of ATP are kept low by the controlled release of these nucleotides and by the clearance of these nucleotides by the soluble or ecto-enzymes CD39, NPP and CD73 (Fig. 2) [43, 52, 53].

There are several mechanisms to clear surfactant from the alveolar space: (1) a small fraction of the surfactant lipids is squeezed out during the respiratory cycles to the bronchiole [66]; (2) degraded surfactant lipids are phagocytised by macrophages which is depending on the cytokine granulocyte macrophage colony-stimulating factor (GM-CSF) signalling through the macrophages GM-CSF receptor CSF2R [40]; (3) SP-D and the G protein-coupled receptor 116 (GPCR116) are involved in the reuptake of surfactant into the AT II cells and the MVBs for recycling purposes. Some of the lipid molecules are taken up by the lysosomes for further degradation [40]; (4) phosphates from degraded lipids are returned to the AT II cells by means of the sodium-dependent phosphate transport protein 2B (coded by the transcription factor SLC34a2) [40].

Obviously, the loss of the alveolar epithelial cells in DAD results in reduced LB surfactant stores and reduced surfactant production. Moreover, surfactant production can be decreased by pulmonary infection [67] and by hyperoxia (ventilation with air with $98 \%$ oxygen content) [68]. Surfactant deactivation by extravasated serum proteins [69] and the conversion of the active to the non-active surfactant subfraction contribute to further surfactant impairment [27]. Loss of surfactant production is accompanied by the deficiency of SP-A and SP-D molecules. As discussed above, SP-A and SP-D are soluble PRRs; they are important components of the innate immunity for the recognition of PAMPs and several DAMPs [41, 42]. Therefore, deficiency of SP-A and SP-D weakens the immune defence against invading pathogens.

\section{Prolonged induced excess of purinergic signalling leads to pro-inflammatory immune response, immunodepression and lung fibrosis}

The effects of purinergic signalling through the binding of nucleotides (ATP, ADP, UTP and UDP) and nucleoside (adenosine) to different receptors on the innate and adaptive immune system are presented in Table 3. This table clarifies the importance of purinergic signalling in the regulation of both pro-inflammatory and anti-inflammatory responses of the immune system and the fibrotic process in the tissues.

\section{Purinergic regulation of the pro-inflammatory responses}

Although many ATP receptors play a role in the activation of the pro-inflammatory immune response (Table 3), activated 


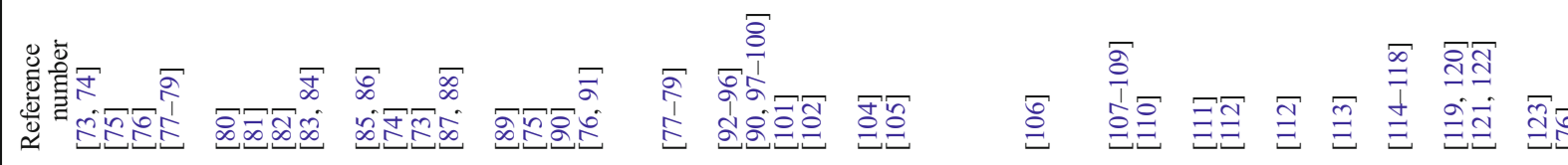

产

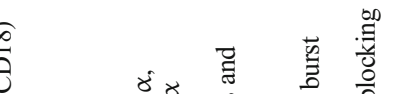

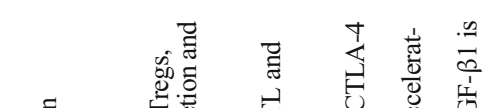

$\stackrel{n}{a}$

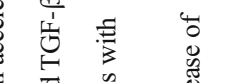

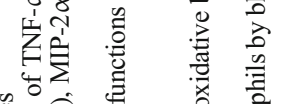

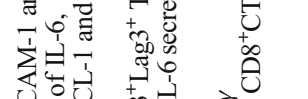

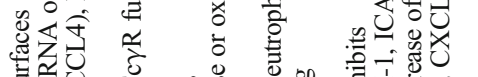

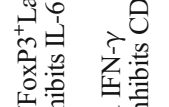

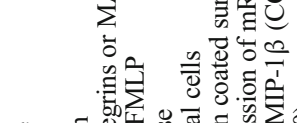

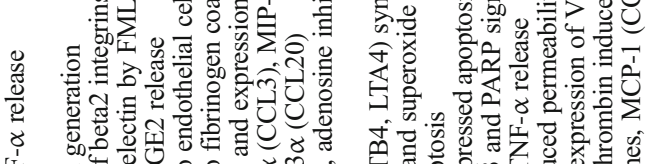

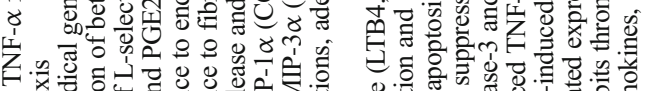

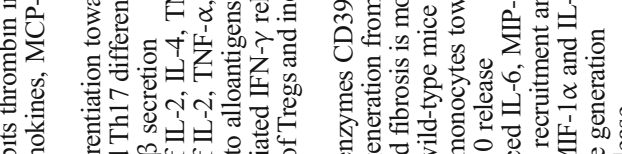

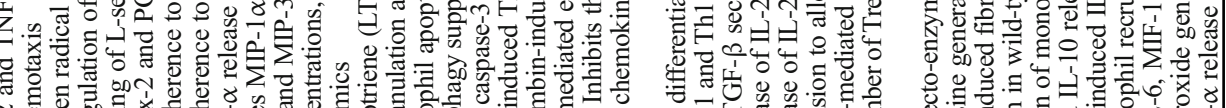

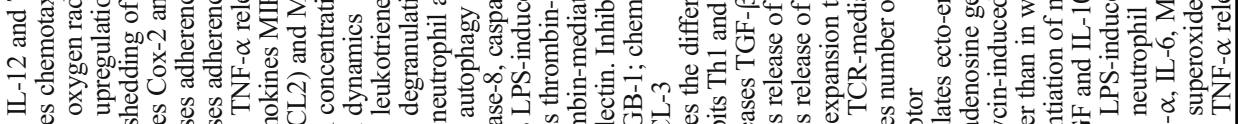

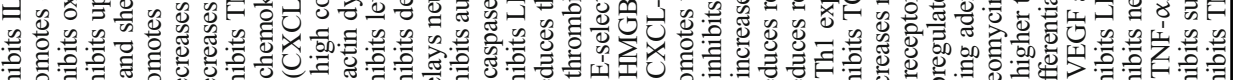

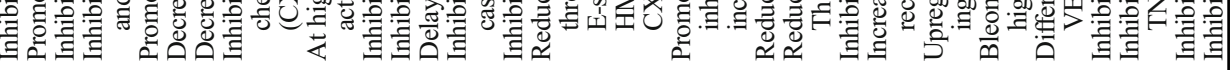

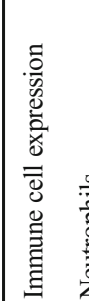

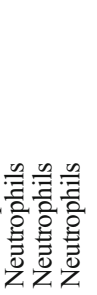

可

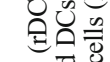

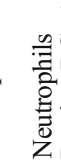

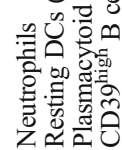

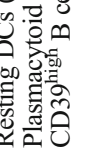

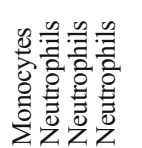
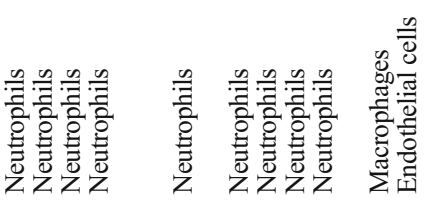

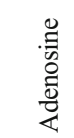

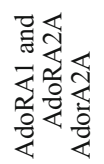

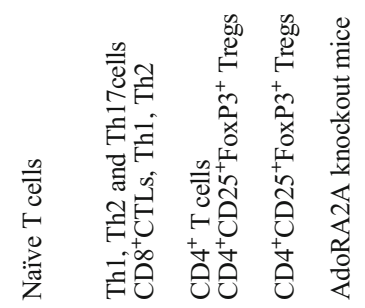
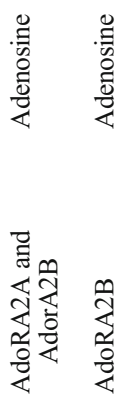


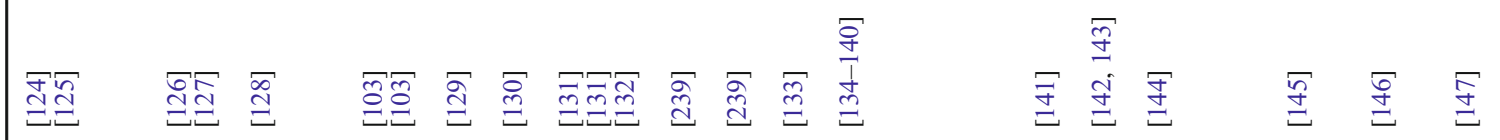

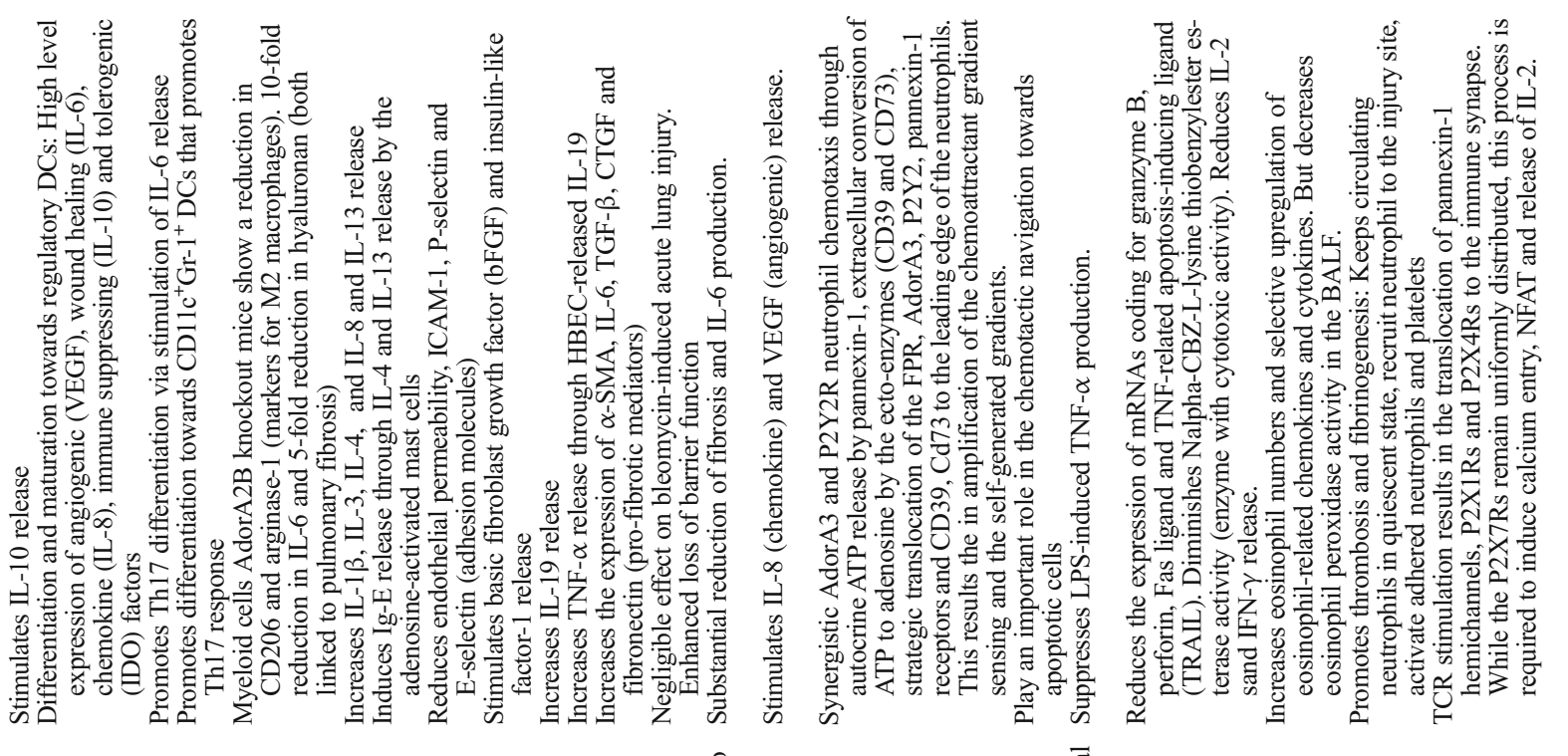

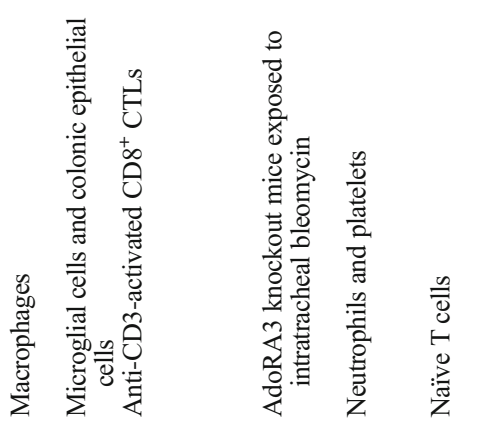

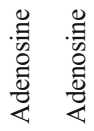

安 安

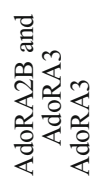

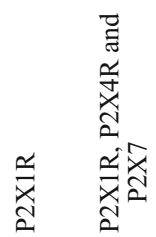

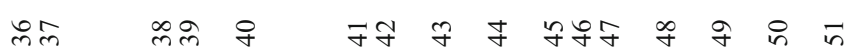

$\therefore$ 的药

in in in 


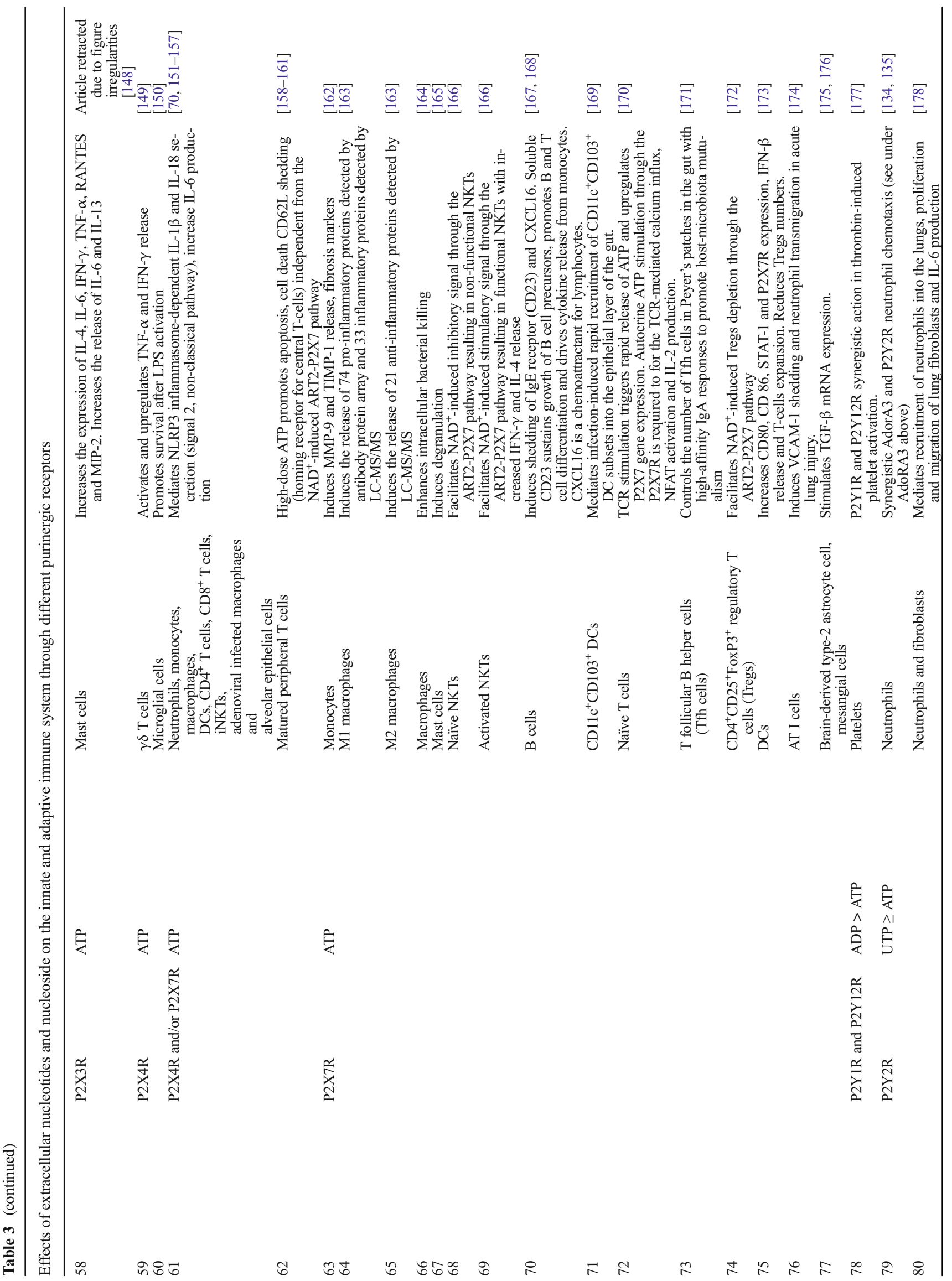




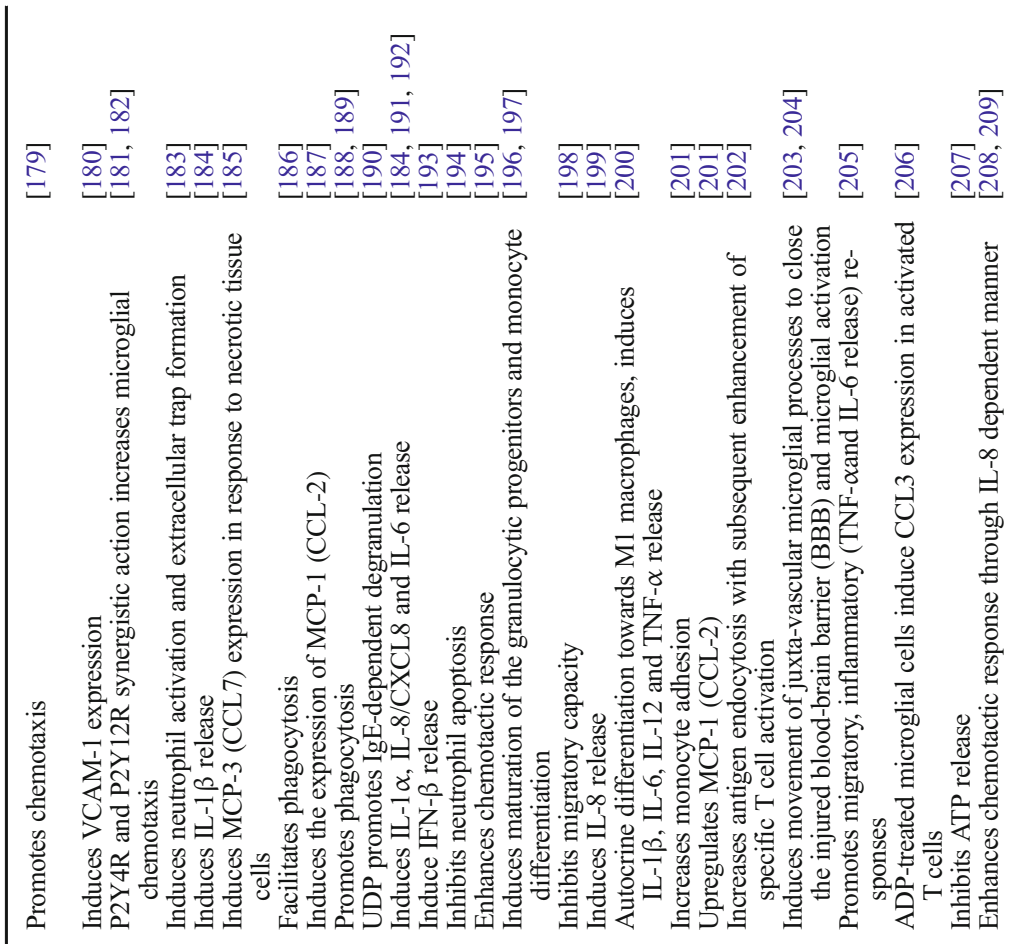

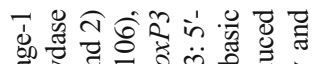

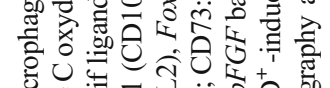

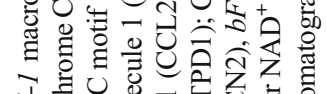

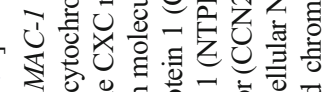
今

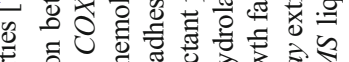
है

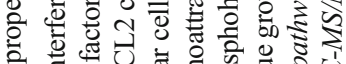

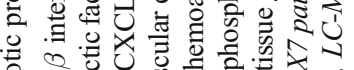

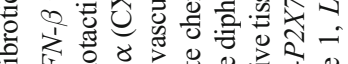

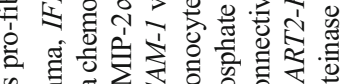

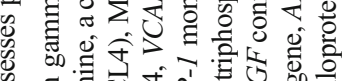

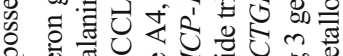
.

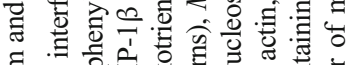

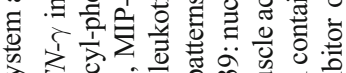

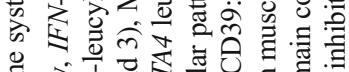

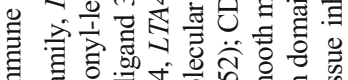

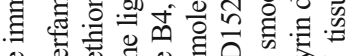

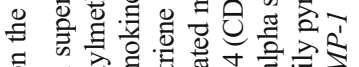

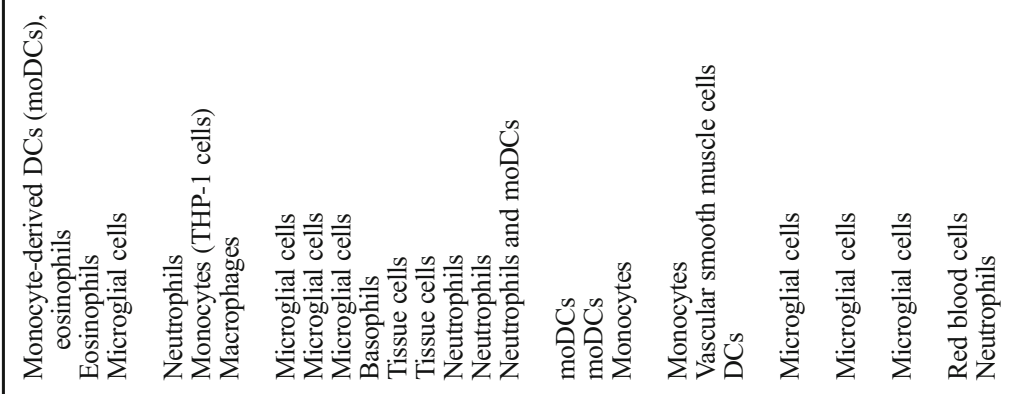

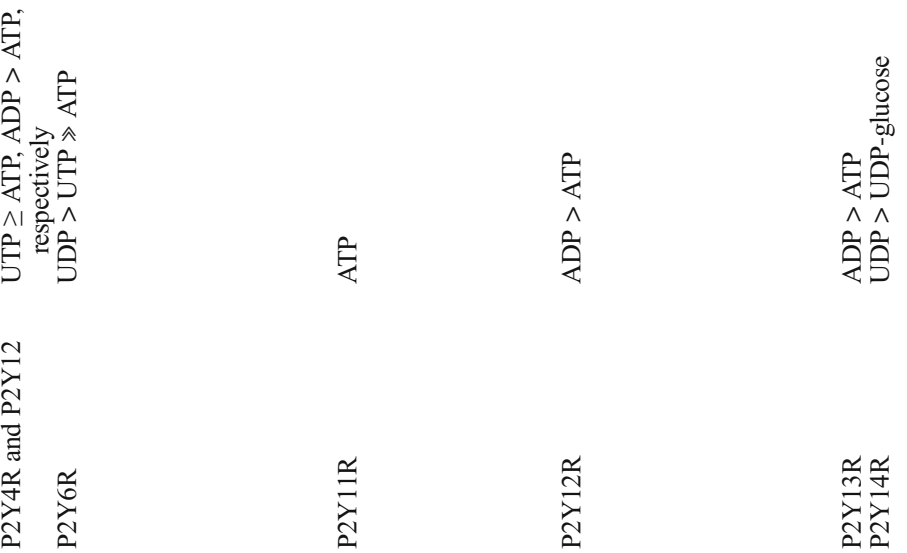

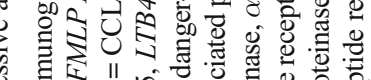

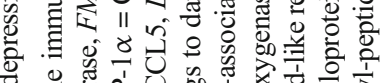

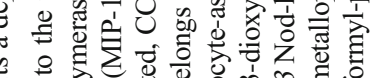
on

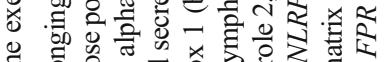

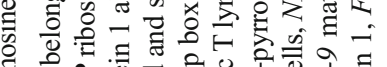
兽 흘 중중 है

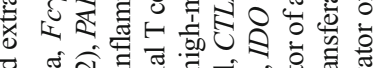
完

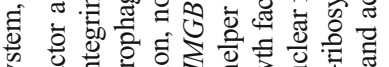

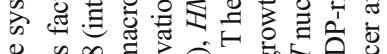

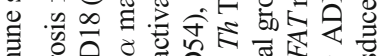
表它

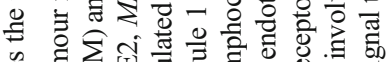

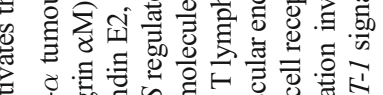

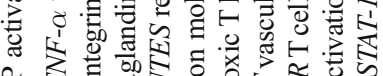

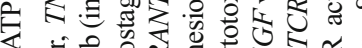

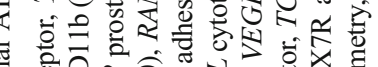

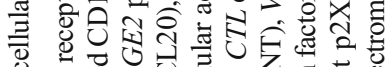

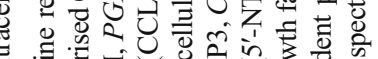

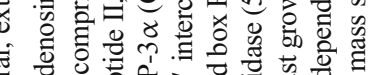
要

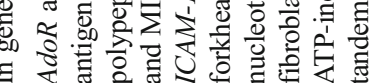


P2X7Rs are important initiators of the pro-inflammatory response by the innate immunity $[43,53,210]$. P2X7R is an ATP receptor and an intrinsic cation channel, but here, the $\mathrm{P} 2 \mathrm{X} 7 \mathrm{R}$ serves as an ATP receptor initiating intracellular transduction. Furthermore, the P2X7Rs have a low affinity for ATP molecules. They are activated only when the concentration of extracellular ATP is quite high reaching millimolar concentrations [70, 211], for example, during a severe inflammation leading to ARDS and/or vigorous mechanical deformation of the AT I cells (Fig. 3). In these conditions with high levels of extracellular ATP, the P2X7R does not appear to exhibit desensitization $[64,215]$. Consequently, high levels of extracellular ATP molecules continuously act as DAMPs and activate the immune system $[43,53,70]$. In case of massive release, ATP may saturate the ATP hydrolysis enzymes CD39 and CD73 causing persistent high ATP levels despite the conversion to adenosine. The resulting pro-inflammatory immune response causes damage to the lung tissue and ends in DAD. Interstitial and alveolar oedema are the result of capillary leakage due to the pro-inflammatory response in the early exudative stage of $\mathrm{DAD}[34,36]$.
Reportedly, another mechanism of the development of alveolar oedema in ARDS after influenza virus infection is proposed $[216,217]$ : influenza virus-induced disruption of the tight junctions between the alveolar epithelia cells and direct inhibition of amiloride-sensitive epithelial sodium channels (ENaCs) [217]. The devastation of the normal alveolar histology in DAD is such that the tight junctions between the epithelial cells are indeed disrupted. But massive ATP release by alveolar epithelial cells after H1N1 influenza A virus (IAV) [218, 219], respiratory syncytial virus (RSV) infection $[220,221]$ and parainfluenza infection virus infection [222] as detected by increased ATP in bronchoalveolar lavage fluid (BALF) have also been reported. Consequently, activation of P2X7Rs in epithelial cells and macrophages after a viral infection results in a pro-inflammatory response of the innate immune system [151] (Table 3, rows 63-66 and row 76) [162-164, 174] and lung tissue injury. Therefore, it is extremely difficult to assess whether the influenza-induced $\mathrm{ENaC}$ inhibition in the lung tissue plays a significant role in the development of alveolar oedema in ARDS with profound capillary leakage as part of the proinflammatory response and disrupted alveolar histology (DAD).

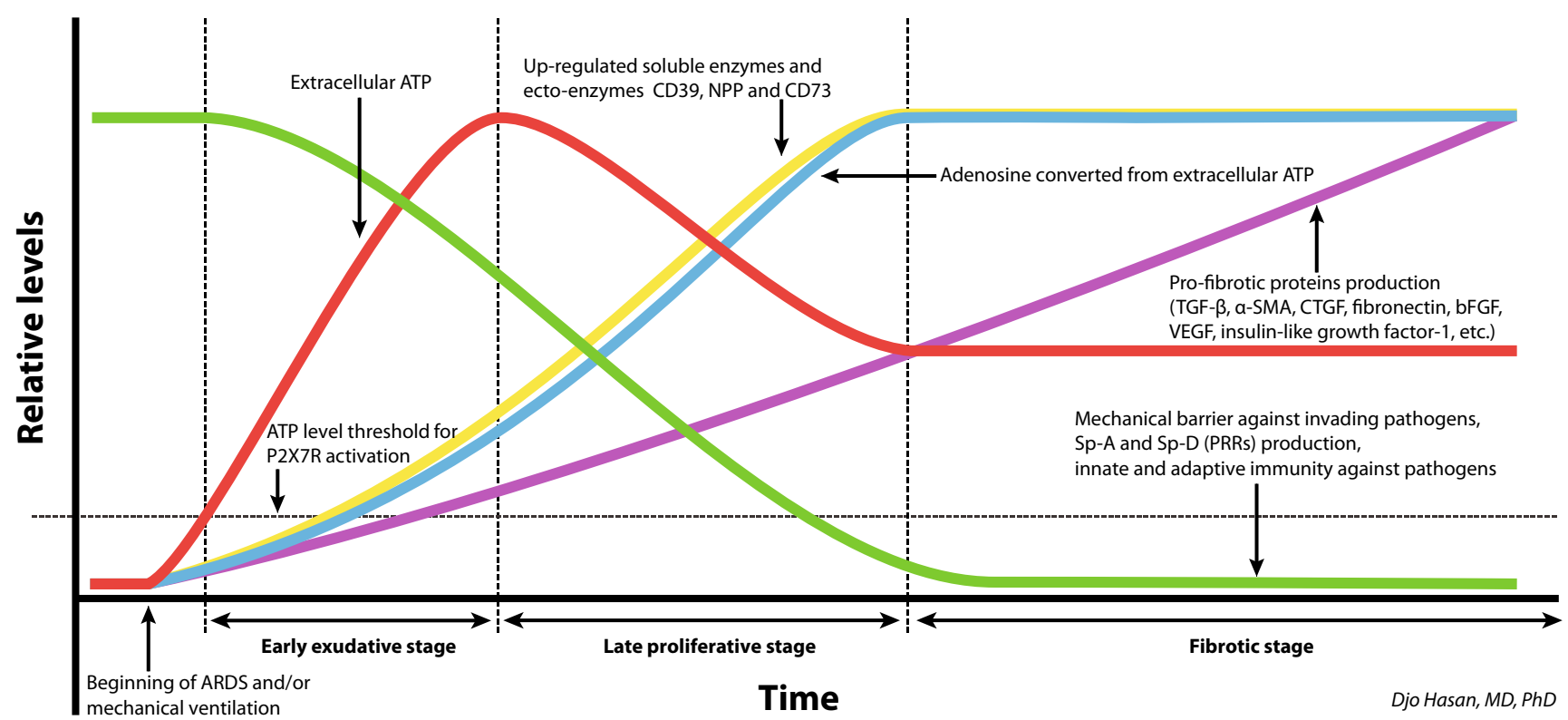

Fig. 3 Putative model of local tissue purinergic signalling, pathogen barriers, adaptive immunity and pro-fibrotic proteins during ARDS and/ or VILI [70]. In the very early phase of ARDS and VILI, infection [43, $52,53]$ and vigorous mechanical deformation of the alveoli by mechanical ventilation $[212,213]$ lead to the substantial increase of extracellular ATP. The ATP levels exceed the threshold for the activation of P2X7R and induce pro-inflammatory immune response [70, 211]. This causes capillary congestion and capillary leakage causing interstitial and alveolar oedema. CD39 expression is upregulated in severe sepsis [214] and after several hours of mechanical ventilation [212]. Consequently, extracellular levels of ATP gradually decrease to a certain extent and extracellular adenosine increases. In general, adenosine has potent anti-inflammatory properties. This may lead to immune paralysis against secondary specific infections. Moreover, lung tissue damage due to DAD is accompanied by the disruption of the physical barrier as a component of the innate immunity for the defence against invading pathogens and by decreased Sp-A and $\mathrm{Sp}-\mathrm{D}$ levels that function as soluble pattern recognition receptors (PRRs) of the innate immune system. This renders the host susceptible to invading pathogens [42]. TGF- $\beta$ expression is increased by the activation of P2X7Rs $[175,176]$ and activation of the adenosine receptor AdoRA2B [132]. AdoRA2B activation also increases the expression of TGF- $\beta$ and other fibrotic factors such as alpha smooth muscle actin $(\alpha-$ SMA), connective tissue growth factor (CTGF or CCN2), IL-6, fibronectin, VEGF, CD206, arginase-1, hyaluronan, basic fibroblast growth factor (bFGF), insulin-like factor-1, etc. (Table 3, rows 40, 44, 47 and 49) [128, 130, 132, 239] 


\section{Conversion of extracellular ATP to adenosine with anti-inflammatory properties.}

After several hours of in vitro mechanical deformation of Calu-3 cells (a human airway epithelial cell line that shows cAMP-dependent $\mathrm{Cl}^{-}$secretion [223]), the messenger RNA (mRNA) levels of CD39 and CD73 are upregulated [212]. Moreover, CD39 expression is upregulated in severe infection such as sepsis [214]. This is probably the consequence of increased TGF- $\beta$ release due to the activation P2X7Rs by extracellular ATP (Table 3, row 77) $[175,176]$ and increased IFN- $\beta$ [224-226] due to the activation of P2Y6Rs by extracellular ATP as presented in Table 3 row 92 [193]. Consequently, extracellular levels of ATP gradually decrease to a certain level, and extracellular adenosine increases. In general, adenosine has potent anti-inflammatory properties. Prolonged high levels of extracellular ATP lead to high levels of extracellular adenosine and to the secondary suppression of the innate and adaptive immune system (Fig. 3). The suppressive effects of extracellular adenosine on the adaptive immune system are presented in Table 3, rows 6-8 [81-84], 24-29 [106-112], 37 [125], 38 [126] and row 104 [206]. Note that adenosine promotes the differentiation of naïve $\mathrm{T}$ cells to $\mathrm{CD}^{+}{ }^{+} \mathrm{FoxP}^{+}{ }^{+} \mathrm{Lag} 3^{+}$Tregs [106], increases the numbers of Tregs [112], increases the expression of the co-inhibitory surface molecule CTLA-4 on Tregs [112] and upregulates the expression of CD39 and CD73 on Tregs [112]. Tregs are potent inhibitors of the activation and function of effector $\mathrm{T}$ cells and potent inhibitors of the maturation and function of DCs [227]. Moreover, Tregs reduce the survival of effector T cells [227]. This causes immune paralysis against secondary specific infections. Additionally, lung tissue damage due to DAD is accompanied by the disruption of the physical barrier, a component of the innate immunity for the defence against invading pathogens and by a decrease of certain soluble PRRs (SP-A and SP-D) production [41, 42].

\section{Intratracheal administered ATP or UTP molecules cause diffuse lung injury}

Confirmation of the role of extracellular ATP in the pathogenesis of VILI is supplied by the following report by Matsuyama et al. [213]: Intratracheally ATP or UTP (100 and $200 \mathrm{mM}$ ) instilled mice showed a progressive increase in wet-to-dry (W/D) weight ratio of the lungs during the first $18 \mathrm{~h}$, the extent of the increased W/D ratio was dose dependent. There was also a significant increase in the albumin permeability index. In comparison to the reference gene glyceraldehyde-3-phosphate dehydrogenase (GAPDH), ATP induced an increase in the gene expression (mRNA) of macrophage inflammatory protein-2 (MIP-2), TNF- $\alpha$ and IL-6 detected using real-time polymerase chain reaction (RT-PCR) within 60 min after the administration [213]. Note that the gene expression of IL-1 $\beta$ was not increased because ATP regulates the posttranscriptional activation of NLRP3 inflammasomes [152, 228, 229], and this cannot be detected with the applied RT-PCR technique. There was a considerable rise in the number of neutrophil and macrophage counts in the BALF. These effects appeared in intratracheally ATP instilled mice and in mice mechanically ventilated with a $V_{\mathrm{T}}$ of $40 \mathrm{ml} / \mathrm{kg}$ ideal body weight but not with a $V_{\mathrm{T}}$ of $8 \mathrm{ml} / \mathrm{kg}$. The ATP levels in BALF specimens in the high $V_{\mathrm{T}}$ group were significantly increased when compared to the low $V_{\mathrm{T}}$ group. In addition, the increased W/D weight ratio, albumin permeability and cytokine production (with the exception of TNF- $\alpha$ ) in the intratracheal ATP group were mitigated by the administration of pyridoxal-5'-phosphate-6-azophenyl-2', 4'-disulfonic acid (PPADS), a semi-selective antagonist of the purinergic receptor P2X and P2Y purinergic receptors [213].

\section{Increased extracellular ATP levels to micromolar concentrations and conversion of very high levels of extracellular ATP (millimolar concentrations) to adenosine improve survival}

Belete et al. applied five incremental steps of strain $(0,0.03$, $0.06,0.08,0.10,0.18$, respectively) to experimental AT I cell monolayers [230]. Strain was defined as the proportion of radial length change of the monolayer during each stretch cycle. They found that the extent of the applied cell strain was proportional to the extracellular level of ATP and the extent of plasma membrane damage. Adding a small amount of ATP $(10 \mu \mathrm{M})$ or ecto-enzyme inhibitor ARL 67156 $(100 \mu \mathrm{M})$ decreased the proportion of the lethally wounded AT I cells. The addition of adenosine $(5 \mu \mathrm{g} / \mathrm{ml})$ did not provide increased cytoprotection. The addition of apyrase (20 U/ $\mathrm{ml})$ or apyrase combined with ADA $(5 \mathrm{U} / \mathrm{ml})$ to increase the extracellular adenosine levels at the expense of the extracellular ATP levels caused an increase in the proportion of the lethally wounded AT I cells ruling out a potential adenosynergic cytoprotection pathway. Apparently, elevated extracellular ATP levels to micromolar concentrations facilitated the plasma membrane wound healing by increasing the fusion of the calcium-sensitive lysosomes with the plasma membrane at the wound site. ATP induced this process in the AT I cells in an autocrine manner through the P2Y2Rs activating the $\mathrm{IP}_{3}$ and DAG/PKC pathways [230]. This process is similar to the paracrine ATP-induced fusion of the LBs with the cell membrane of the AT II cells [54, 55, 59].

Eckle et al. reported that the gene expression of the enzymes CD39 and CD73 that hydrolyse ATP to adenosine in the wild-type (WT) mice lungs was increased during mechanical ventilation with very high inspiratory pressure of $45 \mathrm{mbar}$ (equivalent to $45.9 \mathrm{~cm} \mathrm{H}_{2} \mathrm{O}$ ) [212]. At this inspiratory pressure level, the lung volume reached TLC with a strain of 2.5 (strain was defined as the inspiratory volume divided by the functional residual capacity) [20, 231]. In CD39-/- and in 
CD73-/- knockout mice, diffuse lung injury was far more severe than in the WT mice [212]. Intraperitoneal administration of soluble CD39 in CD39-/- mice and soluble CD73 in CD73-/- mice attenuated the lung injury severity to the level of the WT mice [212]. In addition, intraperitoneal administration of soluble CD39 or CD73 in WT mice treated with the injurious mechanical ventilation increased the survival significantly, decreased the VILI score and increased the pulmonary adenosine levels [212]. As mentioned above, the very high strain levels cause a massive ATP release saturating the ATP hydrolysis enzymes CD39 and CD73 with persisting high ATP levels. The administered soluble CD39 and CD73 convert the excessive ATP molecules to adenosine causing the inflammatory ATP levels to drop and the anti-inflammatory adenosine levels to rise. In addition, adenosine attenuates the ventilator-induced capillary leakage through AdoRA2B receptor signalling (Table 3, row 43) [129].
As stated earlier, the ATP hydrolysing enzymes CD39 and CD73 are upregulated during mechanical ventilation. One of the factors that leads to the upregulation of CD73 is the increased expression of IFN- $\beta$ [224-226] by the activation of P2Y6Rs [193]. Reportedly, intravenous administration of IFN- $\beta$ - 1 a reduces mortality in patients with ARDS treated with assisted mechanical ventilation significantly [232].

\section{High levels of extracellular adenosine end in pulmonary fibrosis}

On the other hand, when the extracellular ATP levels remain high due to continuous massive release of ATP, adenosine accumulates in the extracellular space due to the overload of the ADA enzyme and of the re-uptake process of adenosine through ENTs and CNTs (Fig. 2). Prolonged high levels of extracellular adenosine result in immunosuppression, the
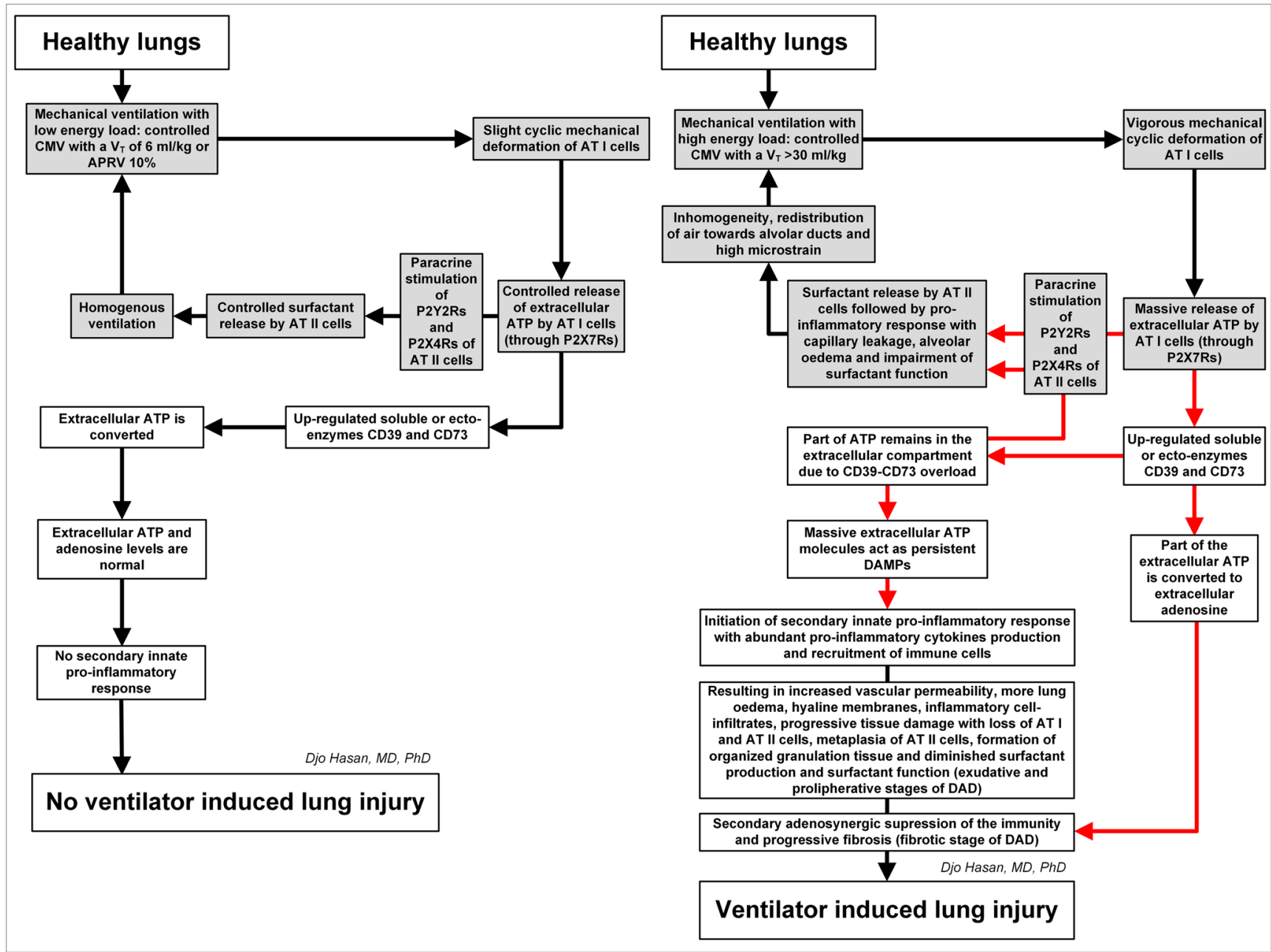

Fig. 4 The summary of the physiological, pathophysiological and immunological consequences of controlled CMV with a $V_{\mathrm{T}} \leq 6 \mathrm{ml} / \mathrm{kg}$ ideal body weight (left) and of controlled CMV with extremely high $V_{\mathrm{T}}$ (right) in healthy lungs (see text for explanation). The common cell signalling pathway for the release of surfactant by alveolar epithelial type 2 (AT II) cells and for the activation of the innate immunity (red

arrows). Sequential processes related to mechanical ventilation (grey coloured text boxes). CMV continuous mandatory ventilation, $V_{\mathrm{T}}$ tidal volume, APRV $10 \%$ airway pressure release ventilation with the expiration termination set at $10 \%$ of the peak-expiratory flow rate (PEFR), DAMPS danger-associated molecular patterns, $D A D$ diffuse alveolar damage 
production of fibrotic proteins and finally end in fibrosis (Fig. 3). Reportedly, adenosine-dependent fibrosis occurs in mice with ADA deficiency. In these mice, ADA suppletion leads to the resolution of the fibrosis [233, 234]. On top of the increased TGF- $\beta$ expression by the activation of P2X7Rs (Table 3, row 77) [175, 176], activation of AdoRA2B increases the expression of TGF- $\beta, \alpha$-SMA, connective tissue growth factor (CTGF or CCN2), IL-6 and fibronectin in fibroblasts. These proteins are known to be pro-fibrotic (Table 3, row 47) (Fig. 3) [132]. One of the pro-fibrotic properties of TGF- $\beta$ is the induction of epithelial-to-mesenchymal transition (EMT), a fundamental underlying pathogenic factor in lung fibrosis [235]. Presumably, treatment with IFN- $\beta-1$ a, with soluble CD39 or with CD73, increases the adenosine levels. In turn, this probably leads to a significant decrease in extracellular ATP reducing the inflammation and the release of extracellular ATP by the lung tissue cells and the immune cells. For a proportion of patients [232] and experimental animals [212], this may well be enough to halt the progression of DAD.

\section{Summary and conclusion}

We summarise the physiological, pathophysiological and immunobiological consequences of controlled CMV, APRV 10\% and APRV 75\% in Figs. 4 and 5.

Diffuse lung tissue damage induced by systemic or local infection, trauma or haemorrhagic shock and mechanical ventilation all use a common cell signalling pathway to cause VILI. This pathway is as follows: AT I cells are the mechanosensors in the lung; the AT I cells secrete large quantities of ATP molecules after being infected or being vigorously stretched or compressed. This is followed by the paracrine stimulation of AT II cells by the extracellular ATP molecules leading to the unpacking of the LBs to the alveolar space. In infections, many infected immune cells and tissue cells (such as AT I and AT II cells) release ATP without requiring mechanical deformation of the cells.

Although increased extracellular ATP levels to micromolar concentrations may provide cytoprotection against stretched-

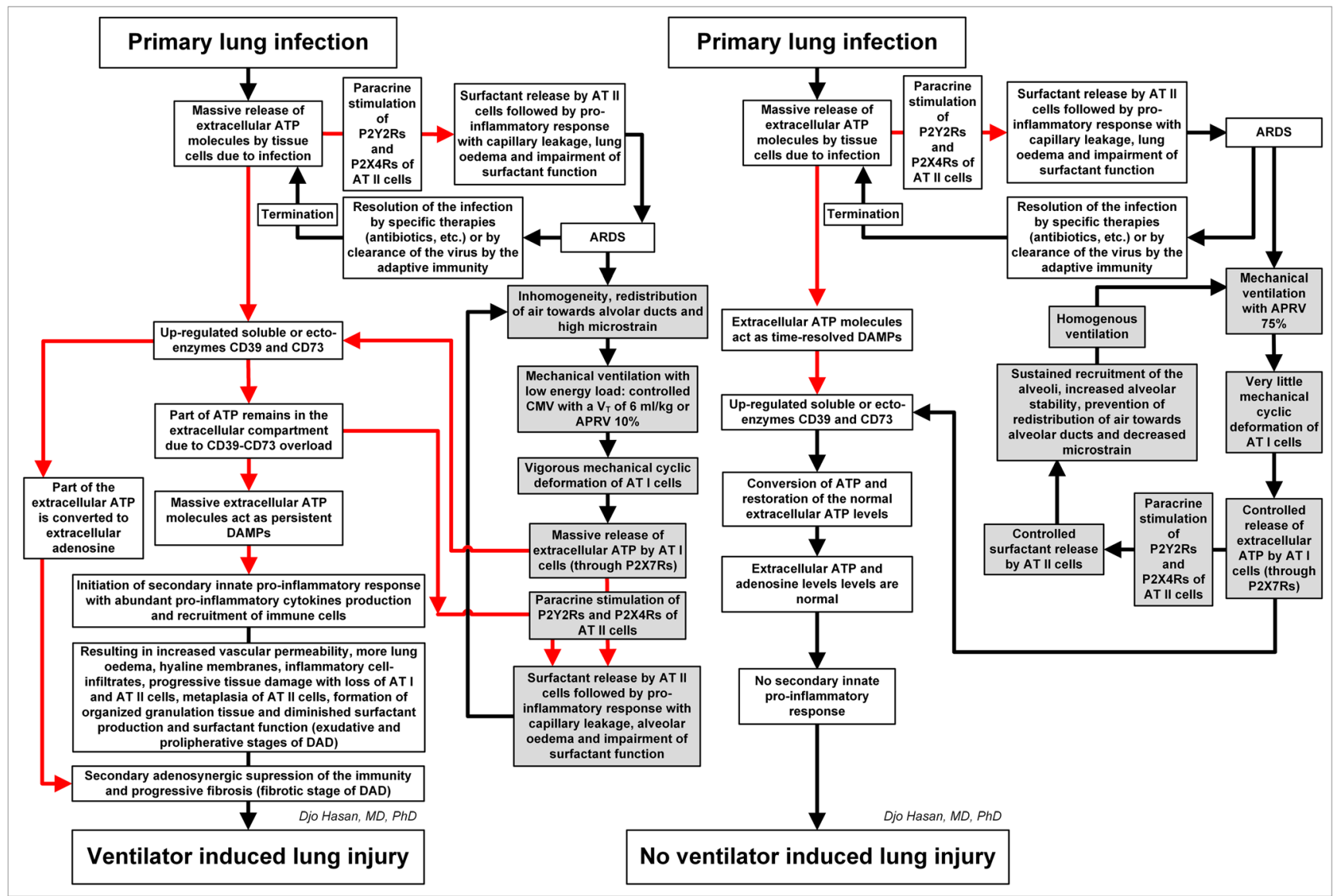

Fig. 5 The summary of the physiological, pathophysiological and immunological consequences of controlled CMV with a $V_{\mathrm{T}} \leq 6 \mathrm{ml} / \mathrm{kg}$ ideal body weight or APRV 10\% (left) and of APRV 75\% (right) in infected lungs (see text for explanation). The common cell signalling pathway for the release of surfactant by alveolar epithelial type 2 (AT II) cells and for the activation of the innate immunity (red arrows). Sequential processes related to mechanical ventilation (grey coloured text boxes). $C M V$ continuous mandatory ventilation, $V_{\mathrm{T}}$ tidal volume, $A P R V 75 \%$ airway pressure release ventilation with the expiration termination set at $75 \%$ of the peak-expiratory flow rate (PEFR), APRV $10 \%$ APRV with the expiration termination set at $10 \%$ of the PEFR, $D A M P s$ danger-associated molecular patterns, $D A D$ diffuse alveolar damage 
induced plasma membrane damage by the facilitation of plasma membrane repair, very high levels (millimolar concentrations) of extracellular ATP activate the innate immune system by several other pathways: neutrophil recruitment and transmigration to the lung tissue, production of the proinflammatory cytokines IL-1 $\beta$ and IL-18, polarization of the macrophages towards M1 phenotype, etc. The resulting inflammation causes diffuse damage of the lung tissue and results in DAD. In addition, damage to the AT I and AT II cells (due to DAD) results in a decrease in surfactant production, extravasated serum proteins and the conversion of the active to the non-active surfactant subfraction ending in surfactant function impairment. The escalation of this process by ventilation (controlled CMV or APRV 10\%) increases the extracellular ATP levels and surfactant impairment even further. Persistent release of extracellular ATP is followed by the upregulation of the ecto-enzymes (CD39 and CD73) decreasing extracellular ATP levels by conversion to adenosine. High levels of adenosine are associated with immune paralysis against invading pathogens and progressive lung fibrosis.

When the levels of the extracellular ATP are such that treatment with soluble CD39, CD73 or IFN- $\beta$ is sufficient to reduce the pro-inflammatory response and restore the surfactant function, VILI development will be stopped and the lungs may recover. When the extent of lung damage is more severe and extensive with persistent high levels of extracellular ATP, conversion of extracellular ATP to adenosine does not lead to the recovery of the surfactant function but instead leads to very high levels of extracellular adenosine. In this case, VILI will progress to the next (fibrotic) stage (Fig. 3).

Mechanical ventilation by means of controlled CMV or APRV $10 \%$ with relatively long expiration time results in cyclic recruitment of the surfactant-deactivated alveoli causing a redistribution of the inspired air volume from the non-recruited alveoli to the alveolar ducts. In addition, cyclic recruitment leads to an increase in the volume difference between inspiration and expiration in the alveolar ducts and therefore increases the microstrain. Increased microstrain is associated with the increase of mechanical deformation of the alveoli causing an increase in extracellular ATP release. This ends in a vicious circle of mechanical tissue damage $\rightarrow$ massive ATP release $\rightarrow$ increased inflammation $\rightarrow$ surfactant function impairment $\rightarrow$ exacerbating mechanical tissue damage $\rightarrow$ massive ATP release $\rightarrow$ etc. (Figs. 4 (right panel) and 5 (left panel)).

The essence of the prevention of VILI is to escape this vicious circle by decreasing the extracellular levels of ATP in the lung tissue either by the administration of IFN- $\beta$ [232], soluble CD39 and soluble CD73 [212] or by continuously recruiting the alveoli until all are recruited and to keep the recruited alveoli open [8]. This ventilator strategy prevents the redistribution of inspired air towards the alveolar ducts, stabilises the alveoli, minimises the microstrain and limits the release of extracellular ATP by the cells, especially by the AT I cells. Consequently, the innate immune response is reduced, and the AT I, AT II cells and surfactant function are restored. Properly set, APRV 75\% appeared to do just that by opening the lung and keeping it open, in experimental settings [7811] and in a clinical statistical analysis [9] (Fig. 5 (right panel)). The rationale behind the lung tissue protective effect of the APRV $75 \%$-induced recruitment and stabilization in surfactant-impaired ARDS model in animals is through understanding dynamic alveolar mechanics. Alveoli are not elastic (i.e. change size in a one to one relationship with the applied stress, which would be the $V_{\mathrm{T}}$ ); rather, alveoli are a viscoelastic system. A viscoelastic system is represented best by the spring and dashpot [240]. In a viscoelastic system, there is a delay in the strain (i.e. change in alveolar size) following the applied stress, which in the case of the lung is the inspiratory pressure. At least two conditions have to be fulfilled to recruit the collapsed viscoelastic alveoli: (1) sufficiently high airway pressure of $>30 \mathrm{~cm} \mathrm{H}_{2} \mathrm{O}$ and (2) long enough duration of the pressure (varies between $2 \mathrm{~s}$ and several minutes for the individual alveolus due to the inhomogeneous nature of the collapsed alveoli) to allow the alveoli to be recruited [236, 237]. This is known as the creep phenomenon of the viscoelastic system [240]. Thus, by extending the time at inspiration (i.e. increasing the duration of the applied stress), we gradually 'nudge' alveoli open over time [236]. Fully recruiting the lung eliminates stress concentrators, a major VILI mechanism [238]. The lung is stabilised by a very short time at expiration. If the stress (i.e. inspiratory pressure) is released very quickly for a very short time, the viscoelastic alveoli will not have time to empty, maintaining a PEEP. Thus, the short expiratory duration stabilises the lung by two mechanisms: time and pressure. Using our understanding of dynamic alveolar mechanics and the fact that alveoli are viscoelastic, we use the MBP parameter of duration to open and stabilise the lung. Using a short expiratory duration stabilises alveoli and prevents the redistribution of the inspired air towards the alveolar ducts and prevents vigorous cyclic deformation of the alveoli [8], which, in turn, prevents massive extracellular ATP release, massive short-term surfactant release, followed by surfactant function impairment, interstitial and alveolar oedema and activation of the innate immunity leading to the development or aggravation of DAD. This presumably prevents the loss of AT I cells, prevents the hyperplasia of AT II cells and restores the surfactant function, and the affected lung regions start to regain their normal compliance (increase their alveolar time constant).

Acknowledgments We are grateful to Prof. Dr. Diederik Gommers, chairman of the Department of Adult ICU of the University Hospital Erasmus MC Rotterdam (NL) for his invaluable comments during the preparation of the manuscript. We thank Philip van der Zee, MD, researcher at the Department of Adult ICU of the University Hospital 
Erasmus MC Rotterdam (NL) for his efforts in the preparation of the manuscript.

\section{Compliance with ethical standards}

Conflict of interest Djo Hasan and Paul Blankman declare no competing financial interests.

Gary F. Nieman have received travel cost and honoraria at events sponsored by Dräger Medical. I have lectured for Intensive Care Online (ICON) without compensation.

Ethical approval This article does not contain any studies with human participants or animals performed by any of the authors.

Open Access This article is distributed under the terms of the Creative Commons Attribution 4.0 International License (http:// creativecommons.org/licenses/by/4.0/), which permits unrestricted use, distribution, and reproduction in any medium, provided you give appropriate credit to the original author(s) and the source, provide a link to the Creative Commons license, and indicate if changes were made.

\section{References}

1. Sweeney RM, McAuley DF (2016) Acute respiratory distress syndrome. Lancet (London, England). doi:10.1016/s01406736(16)00578-X

2. Zhang Y, Sun H, Fan L, Ma Y, Sun Y, Pu J, Yang J, Qiao J, Ma G, Liu J (2012) Acute respiratory distress syndrome induced by a swine 2009 H1N1 variant in mice. PLoS One 7(1):e29347. doi: 10.1371/journal.pone.0029347

3. Xu T, Qiao J, Zhao L, Wang G, He G, Li K, Tian Y, Gao M, Wang J, Wang H, Dong C (2006) Acute respiratory distress syndrome induced by avian influenza A (H5N1) virus in mice. Am J Respir Crit Care Med 174(9):1011-1017. doi:10.1164/rccm.2005111751OC

4. Li Y, Shan Y, Chi Y, Wen T, Han X (2014) Acute lung injury induced by H9N2 virus in mice. Chin Med J 127(20):3576-3580

5. Deng G, Bi J, Kong F, Li X, Xu Q, Dong J, Zhang M, Zhao L, Luan Z, Lv N, Qiao J (2010) Acute respiratory distress syndrome induced by H9N2 virus in mice. Arch Virol 155(2):187-195. doi: 10.1007/s00705-009-0560-0

6. Protti A, Andreis DT, Milesi M, Iapichino GE, Monti M, Comini B, Pugni P, Melis V, Santini A, Dondossola D, Gatti S, Lombardi L, Votta E, Carlesso E, Gattinoni L (2015) Lung anatomy, energy load, and ventilator-induced lung injury. Intensive Care Med Exp 3(1):34. doi:10.1186/s40635-015-0070-1

7. Roy S, Habashi N, Sadowitz B, Andrews P, Ge L, Wang G, Roy P, Ghosh A, Kuhn M, Satalin J, Gatto LA, Lin X, Dean DA, Vodovotz Y, Nieman G (2013) Early airway pressure release ventilation prevents ARDS-a novel preventive approach to lung injury. Shock (Augusta, Ga) 39(1):28-38. doi:10.1097/SHK. 0b013e31827b47bb

8. Kollisch-Singule M, Emr B, Smith B, Ruiz C, Roy S, Meng Q, Jain S, Satalin J, Snyder K, Ghosh A, Marx WH, Andrews P, Habashi N, Nieman GF, Gatto LA (2014) Airway pressure release ventilation reduces conducting airway micro-strain in lung injury. J Am Coll Surg 219(5):968-976

9. Andrews PL, Shiber JR, Jaruga-Killeen E, Roy S, Sadowitz B, O'Toole RV, Gatto LA, Nieman GF, Scalea T, Habashi NM (2013) Early application of airway pressure release ventilation may reduce mortality in high-risk trauma patients: a systematic review of observational trauma ARDS literature. J Trauma Acute Care Surg 75(4):635-641. doi:10.1097/TA.0b013e31829d3504
10. Emr B, Gatto LA, Roy S, Satalin J, Ghosh A, Snyder K, Andrews P, Habashi N, Marx W, Ge L, Wang G, Dean DA, Vodovotz Y, Nieman G (2013) Airway pressure release ventilation prevents ventilator-induced lung injury in normal lungs. JAMA Surg 148(11):1005-1012

11. Kollisch-Singule M, Emr B, Jain SV, Andrews P, Satalin J, Liu J, Porcellio E, Kenyon V, Wang G, Marx W, Gatto LA, Nieman GF, Habashi NM (2015) The effects of airway pressure release ventilation on respiratory mechanics in extrapulmonary lung injury. Intensive Care Med Exp 3(1):35. doi:10.1186/s40635-015-0071-0

12. Kollisch-Singule M, Emr B, Smith B, Roy S, Jain S, Satalin J, Snyder K, Andrews P, Habashi N, Bates J, Marx W, Nieman G, Gatto LA (2014) Mechanical breath profile of airway pressure release ventilation: the effect on alveolar recruitment and microstrain in acute lung injury. JAMA Surg 149(11):11381145. doi:10.1001/jamasurg.2014.1829

13. Roy SK, Emr B, Sadowitz B, Gatto LA, Ghosh A, Satalin JM, Snyder KP, Ge L, Wang G, Marx W, Dean D, Andrews P, Singh A, Scalea T, Habashi N, Nieman GF (2013) Preemptive application of airway pressure release ventilation prevents development of acute respiratory distress syndrome in a rat traumatic hemorrhagic shock model. Shock (Augusta, Ga) 40(3):210-216. doi:10.1097/ SHK.0b013e31829efb06

14. Sadowitz B, Jain S, Kollisch-Singule M, Satalin J, Andrews P, Habashi N, Gatto LA, Nieman G (2016) Preemptive mechanical ventilation can block progressive acute lung injury. World J Crit Care Med 5(1):74-82. doi:10.5492/wjccm.v5.i1.74

15. Dreyfuss D, Hubmayr R (2016) What the concept of VILI has taught us about ARDS management. Intensive Care Med 42(5): 811-813. doi:10.1007/s00134-016-4287-6

16. Nieman GF, Gatto LA, Habashi NM (2015) Impact of mechanical ventilation on the pathophysiology of progressive acute lung injury. J Appl Physiol (1985) 119(11):1245-1261

17. Slutsky AS, Ranieri VM (2013) Ventilator-induced lung injury. N Engl J Med 369(22):2126-2136

18. Gattinoni L, Marini JJ, Pesenti A, Quintel M, Mancebo J, Brochard L (2016) The "baby lung" became an adult. Intensive Care Med 42(5):663-673. doi:10.1007/s00134-015-4200-8

19. Kroon AA, Wang J, Huang Z, Cao L, Kuliszewski M, Post M (2010) Inflammatory response to oxygen and endotoxin in newborn rat lung ventilated with low tidal volume. Pediatr Res 68(1): 63-69. doi:10.1203/00006450-201011001-00120

20. Protti A, Andreis DT, Monti M, Santini A, Sparacino CC, Langer T, Votta E, Gatti S, Lombardi L, Leopardi O, Masson S, Cressoni M, Gattinoni L (2013) Lung stress and strain during mechanical ventilation: any difference between statics and dynamics? Crit Care Med 41(4):1046-1055. doi:10.1097/CCM. 0b013e31827417a6

21. Protti A, Maraffi T, Milesi M, Votta E, Santini A, Pugni P, Andreis DT, Nicosia F, Zannin E, Gatti S, Vaira V, Ferrero S, Gattinoni L (2016) Role of strain rate in the pathogenesis of ventilator-induced lung edema. Crit Care Med 44(9):e838-e845. doi:10.1097/ccm. 0000000000001718

22. Steinberg J, Schiller HJ, Halter JM, Gatto LA, Dasilva M, Amato M, McCann UG, Nieman GF (2002) Tidal volume increases do not affect alveolar mechanics in normal lung but cause alveolar overdistension and exacerbate alveolar instability after surfactant deactivation. Crit Care Med 30(12):2675-2683. doi:10.1097/01. ccm.0000038087.84531.8d

23. Bachofen H, Schurch S (2001) Alveolar surface forces and lung architecture. Comp Biochem Physiol A Mol Integr Physiol 129(1):183-193

24. Habashi NM (2005) Other approaches to open-lung ventilation: airway pressure release ventilation. Crit Care Med 33(3 Suppl): S228-S240 
25. Jain SV, Kollisch-Singule M, Sadowitz B, Dombert L, Satalin J, Andrews P, Gatto LA, Nieman GF, Habashi NM (2016) The 30year evolution of airway pressure release ventilation (APRV). Intensive Care Med Exp 4(1):11. doi:10.1186/s40635-016-0085-2

26. Wyszogrodski I, Kyei-Aboagye K, Taeusch HW Jr, Avery ME (1975) Surfactant inactivation by hyperventilation: conservation by end-expiratory pressure. J Appl Physiol 38(3):461-466

27. Verbrugge SJ, Bohm SH, Gommers D, Zimmerman LJ, Lachmann B (1998) Surfactant impairment after mechanical ventilation with large alveolar surface area changes and effects of positive end-expiratory pressure. Br J Anaesth 80(3):360-364

28. Brower RG, Matthay MA, Morris A, Schoenfeld D, Thompson BT, Wheeler A, The Acute Respiratory Distress Syndrome Network (2000) Ventilation with lower tidal volumes as compared with traditional tidal volumes for acute lung injury and the acute respiratory distress syndrome. N Engl J Med 342(18):1301-1308. doi:10.1056/nejm200005043421801

29. Aeffner F, Bolon B, Davis IC (2015) Mouse models of acute respiratory distress syndrome: a review of analytical approaches, pathologic features, and common measurements. Toxicol Pathol 43(8):1074-1092. doi:10.1177/0192623315598399

30. Rocco PR, Nieman GF (2016) ARDS: what experimental models have taught us. Intensive Care Med 42(5):806-810. doi:10.1007/ s00134-016-4268-9

31. Kao KC, Hu HC, Chang CH, Hung CY, Chiu LC, Li SH, Lin SW, Chuang LP, Wang CW, Li LF, Chen NH, Yang CT, Huang CC, Tsai YH (2015) Diffuse alveolar damage associated mortality in selected acute respiratory distress syndrome patients with open lung biopsy. Crit Care 19:228. doi:10.1186/s13054-015-0949-y

32. Lorente JA, Cardinal-Fernandez P, Munoz D, Frutos-Vivar F, Thille AW, Jaramillo C, Ballen-Barragan A, Rodriguez JM, Penuelas O, Ortiz G, Blanco J, Pinheiro BV, Nin N, del Carmen MM, Esteban A, Thompson TB (2015) Acute respiratory distress syndrome in patients with and without diffuse alveolar damage: an autopsy study. Intensive Care Med 41(11):1921-1930. doi:10. 1007/s00134-015-4046-0

33. Thille AW, Esteban A, Fernandez-Segoviano P, Rodriguez JM, Aramburu JA, Penuelas O, Cortes-Puch I, Cardinal-Fernandez P, Lorente JA, Frutos-Vivar F (2013) Comparison of the berlin definition for acute respiratory distress syndrome with autopsy. Am J Respir Crit Care Med 187(7):761-767. doi:10.1164/rccm.20121119810C

34. Castro CY (2006) ARDS and diffuse alveolar damage: a pathologist's perspective. Semin Thorac Cardiovasc Surg 18(1):13-19

35. Thille AW, Esteban A, Fernandez-Segoviano P, Rodriguez JM, Aramburu JA, Vargas-Errazuriz P, Martin-Pellicer A, Lorente JA, Frutos-Vivar F (2013) Chronology of histological lesions in acute respiratory distress syndrome with diffuse alveolar damage: a prospective cohort study of clinical autopsies. Lancet Respir Med 1(5):395-401. doi:10.1016/s2213-2600(13)70053-5

36. Calandrino FS Jr, Anderson DJ, Mintun MA, Schuster DP (1988) Pulmonary vascular permeability during the adult respiratory distress syndrome: a positron emission tomographic study. Am Rev Respir Dis 138(2):421-428

37. Volckaert T, De Langhe S (2014) Lung epithelial stem cells and their niches: Fgf10 takes center stage. Fibrogenesis Tissue Repair 7:8. doi:10.1186/1755-1536-7-8

38. Tomashefski JF Jr (2000) Pulmonary pathology of acute respiratory distress syndrome. Clin Chest Med 21(3):435-466

39. Fukuda Y, Ishizaki M, Masuda Y, Kimura G, Kawanami O, Masugi Y (1987) The role of intraalveolar fibrosis in the process of pulmonary structural remodeling in patients with diffuse alveolar damage. Am J Pathol 126(1):171-182

40. Whitsett JA, Weaver TE (2015) Alveolar development and disease. Am J Respir Cell Mol Biol 53(1):1-7
41. Chroneos ZC, Sever-Chroneos Z, Shepherd VL (2010) Pulmonary surfactant: an immunological perspective. Cellular Physiol Biochem: Int J Exp Cell Physiol, Biochem, Pharmacol 25(1):13-26. doi:10.1159/000272047

42. Whitsett JA, Alenghat T (2015) Respiratory epithelial cells orchestrate pulmonary innate immunity. Nat Immunol 16(1):2735. doi:10.1038/ni.3045

43. Eltzschig HK, Sitkovsky MV, Robson SC (2012) Purinergic signaling during inflammation. N Engl J Med 367(24):2322-2333

44. Burnstock G (2007) Physiology and pathophysiology of purinergic neurotransmission. Physiol Rev 87(2):659-797. doi: 10.1152/physrev.00043.2006

45. Dahl G, Qiu F, Wang J (2013) The bizarre pharmacology of the ATP release channel pannexin1. Neuropharmacol 75:583-593. doi:10.1016/j.neuropharm.2013.02.019

46. Ravichandran KS (2011) Beginnings of a good apoptotic meal: the find-me and eat-me signaling pathways. Immunity 35(4):445455. doi:10.1016/j.immuni.2011.09.004

47. Eltzschig HK, Eckle T, Mager A, Kuper N, Karcher C, Weissmuller T, Boengler K, Schulz R, Robson SC, Colgan SP (2006) ATP release from activated neutrophils occurs via connexin 43 and modulates adenosine-dependent endothelial cell function. Circ Res 99(10):1100-1108. doi:10.1161/01.res. 0000250174.31269.70

48. Faigle M, Seessle J, Zug S, El Kasmi KC, Eltzschig HK (2008) ATP release from vascular endothelia occurs across Cx43 hemichannels and is attenuated during hypoxia. PLoS One 3(7):e2801. doi:10.1371/journal.pone.0002801

49. Fields RD (2011) Nonsynaptic and nonvesicular ATP release from neurons and relevance to neuron-glia signaling. Semin Cell Dev Biol 22(2):214-219. doi:10.1016/j.semcdb.2011.02.009

50. Suadicani SO, Brosnan CF, Scemes E (2006) P2X7 receptors mediate ATP release and amplification of astrocytic intercellular Ca2+ signaling. J Neurosci: Off J Soc Neurosci 26(5):13781385. doi:10.1523/jneurosci.3902-05.2006

51. Brandao-Burch A, Key ML, Patel JJ, Arnett TR, Orriss IR (2012) The P2X7 receptor is an important regulator of extracellular ATP levels. Front Endocrinol 3:41. doi:10.3389/fendo.2012.00041

52. Verkhratsky A, Burnstock G (2014) Biology of purinergic signalling: its ancient evolutionary roots, its omnipresence and its multiple functional significance. BioEssays 36(7):697-705

53. Idzko M, Ferrari D, Eltzschig HK (2014) Nucleotide signalling during inflammation. Nature 509(7500):310-317

54. Mishra A, Chintagari NR, Guo Y, Weng T, Su L, Liu L (2011) Purinergic P2X7 receptor regulates lung surfactant secretion in a paracrine manner. J Cell Sci 124(Pt 4):657-668

55. Dietl P, Haller T, Frick M (2012) Spatio-temporal aspects, pathways and actions of $\mathrm{Ca}(2+)$ in surfactant secreting pulmonary alveolar type II pneumocytes. Cell Calcium 52(3-4):296-302

56. Thompson KE, Korbmacher JP, Hecht E, Hobi N, Wittekindt OH, Dietl P, Kranz C, Frick M (2013) Fusion-activated cation entry (FACE) via P2X(4) couples surfactant secretion and alveolar fluid transport. FASEB J 27(4):1772-1783

57. Patel AS, Reigada D, Mitchell CH, Bates SR, Margulies SS, Koval M (2005) Paracrine stimulation of surfactant secretion by extracellular ATP in response to mechanical deformation. Am J Physiol Lung Cell Mol Physiol 289(3):L489-L496

58. Furuya K, Tan JJ, Boudreault F, Sokabe M, Berthiaume Y, Grygorczyk R (2016) Real-time imaging of inflation-induced ATP release in the ex-vivo rat lung. Am J Physiol Lung Cell Mol Physiol:ajplung. doi:10.1152/ajplung.00425.2015

59. Miklavc P, Mair N, Wittekindt OH, Haller T, Dietl P, Felder E, Timmler M, Frick M (2011) Fusion-activated Ca2+ entry via vesicular P2X4 receptors promotes fusion pore opening and exocytotic content release in pneumocytes. Proc Natl Acad Sci USA 108(35):14503-14508 
60. Chander A, Sen N, Wu AM, Spitzer AR (1995) Protein kinase C in ATP regulation of lung surfactant secretion in type II cells. Am J Phys 268(1 Pt 1):L108-L116

61. Gutierrez AM, Lou X, Erik A, Persson G, Ring A (1999) Ca2+ response of rat mesangial cells to ATP analogues. Eur J Pharmacol 369(1):107-112

62. Gutierrez AM, Lou X, Erik A, Persson G, Ring A (2000) Growth hormones reverse desensitization of $\mathrm{P} 2 \mathrm{Y}(2)$ receptors in rat mesangial cells. Biochem Biophys Res Commun 270(2):594 599. doi:10.1006/bbrc.2000.2461

63. Yan Z, Liang Z, Obsil T, Stojilkovic SS (2006) Participation of the Lys313-Ile333 sequence of the purinergic P2X4 receptor in agonist binding and transduction of signals to the channel gate. J Biol Chem 281(43):32649-32659. doi:10.1074/jbc.M512791200

64. North RA (2002) Molecular physiology of P2X receptors. Physiol Rev 82(4):1013-1067. doi:10.1152/physrev.00015.2002

65. Venereau E, Ceriotti C, Bianchi ME (2015) DAMPs from cell death to new life. Front Immunol 6:422. doi:10.3389/fimmu. 2015.00422

66. Calkovska A, Uhliarova B, Joskova M, Franova S, Kolomaznik M, Calkovsky V, Smolarova S (2015) Pulmonary surfactant in the airway physiology: a direct relaxing effect on the smooth muscle. Respir Physiol Neurobiol 209:95-105

67. Maidji E, Kosikova G, Joshi P, Stoddart CA (2012) Impaired surfactant production by alveolar epithelial cells in a SCID-hu lung mouse model of congenital human cytomegalovirus infection. J Virol 86(23):12795-12805. doi:10.1128/jvi.01054-12

68. Gross NJ, Smith DM (1981) Impaired surfactant phospholipid metabolism in hyperoxic mouse lungs. J Appl Physiol Respir Environ Exerc Physiol 51(5):1198-1203

69. Martinez Sarrasague M, Cimato A, Rubin de Celis E, Facorro G (2011) Influence of serum protein and albumin addition on the structure and activity of an exogenous pulmonary surfactant. Respir Physiol Neurobiol 175(3):316-321. doi:10.1016/j.resp. 2010.12.009

70. Cekic C, Linden J (2016) Purinergic regulation of the immune system. Nat Rev Immunol 16(3):177-192

71. Barletta KE, Ley K, Mehrad B (2012) Regulation of neutrophil function by adenosine. Arterioscler Thromb Vasc Biol 32(4):856864. doi:10.1161/atvbaha.111.226845

72. Burnstock $G$ (2012) Purinergic signalling: its unpopular beginning, its acceptance and its exciting future. BioEssays 34(3): 218-225. doi:10.1002/bies.201100130

73. Cronstein BN, Daguma L, Nichols D, Hutchison AJ, Williams M (1990) The adenosine/neutrophil paradox resolved: human neutrophils possess both $\mathrm{A} 1$ and $\mathrm{A} 2$ receptors that promote chemotaxis and inhibit $\mathrm{O} 2$ generation, respectively. J Clin Invest 85(4): 1150-1157. doi:10.1172/jci114547

74. Rose FR, Hirschhorn R, Weissmann G, Cronstein BN (1988) Adenosine promotes neutrophil chemotaxis. J Exp Med 167(3): 1186-1194

75. Felsch A, Stocker K, Borchard U (1995) Phorbol ester-stimulated adherence of neutrophils to endothelial cells is reduced by adenosine A2 receptor agonists. J Immunol (Baltimore, Md : 1950) 155(1):333-338

76. Thiel M, Chouker A (1995) Acting via A2 receptors, adenosine inhibits the production of tumor necrosis factor-alpha of endotoxin-stimulated human polymorphonuclear leukocytes. J Lab Clin Med 126(3):275-282

77. Salmon JE, Cronstein BN (1990) Fc gamma receptor-mediated functions in neutrophils are modulated by adenosine receptor occupancy. A1 receptors are stimulatory and $\mathrm{A} 2$ receptors are inhibitory. J Immunol (Baltimore, Md: 1950) 145(7):2235-2240

78. Zalavary S, Stendahl O, Bengtsson T (1994) The role of cyclic AMP, calcium and filamentous actin in adenosine modulation of
Fc receptor-mediated phagocytosis in human neutrophils. Biochim Biophys Acta 1222(2):249-256

79. Zalavary S, Bengtsson T (1998) Adenosine inhibits actin dynamics in human neutrophils: evidence for the involvement of cAMP. Eur J Cell Biol 75(2):128-139. doi:10.1016/s0171-9335(98) 80055-1

80. Xu X, Zheng S, Xiong Y, Wang X, Qin W, Zhang H, Sun B (2017) Adenosine effectively restores endotoxin-induced inhibition of human neutrophil chemotaxis via A1 receptor-p38 pathway. Inflammation Res: Off J Eur Histamine Res Soc [et al] 66(4): 353-364. doi:10.1007/s00011-016-1021-3

81. Chen L, Fredholm BB, Jondal M (2008) Adenosine, through the A1 receptor, inhibits vesicular MHC class I cross-presentation by resting DC. Mol Immunol 45(8):2247-2254. doi:10.1016/j. molimm.2007.11.016

82. Schnurr M, Toy T, Shin A, Hartmann G, Rothenfusser S, Soellner J, Davis ID, Cebon J, Maraskovsky E (2004) Role of adenosine receptors in regulating chemotaxis and cytokine production of plasmacytoid dendritic cells. Blood 103(4):1391-1397. doi:10. 1182/blood-2003-06-1959

83. Figueiro F, Muller L, Funk S, Jackson EK, Battastini AM, Whiteside TL (2016) Phenotypic and functional characteristics of CD39high human regulatory B cells (Breg). Oncoimmunol 5(2):e1082703. doi:10.1080/2162402x.2015.1082703

84. Ohtsuka T, Changelian PS, Bouis D, Noon K, Harada H, Lama VN, Pinsky DJ (2010) Ecto-5'-nucleotidase (CD73) attenuates allograft airway rejection through adenosine $2 \mathrm{~A}$ receptor stimulation. J Immunol (Baltimore, Md : 1950) 185(2):1321-1329. doi: 10.4049/jimmunol.0901847

85. Link AA, Kino T, Worth JA, McGuire JL, Crane ML, Chrousos GP, Wilder RL, Elenkov IJ (2000) Ligand-activation of the adenosine A2a receptors inhibits IL-12 production by human monocytes. J Immunol (Baltimore, Md: 1950) 164(1):436-442

86. Zhang JG, Hepburn L, Cruz G, Borman RA, Clark KL (2005) The role of adenosine $\mathrm{A} 2 \mathrm{~A}$ and $\mathrm{A} 2 \mathrm{~B}$ receptors in the regulation of TNF-alpha production by human monocytes. Biochem Pharmacol 69(6):883-889. doi:10.1016/j.bcp.2004.12.008

87. Thiel M, Chambers JD, Chouker A, Fischer S, Zourelidis C, Bardenheuer HJ, Arfors KE, Peter K (1996) Effect of adenosine on the expression of beta(2) integrins and L-selectin of human polymorphonuclear leukocytes in vitro. J Leukoc Biol 59(5): 671-682

88. Wollner A, Wollner S, Smith JB (1993) Acting via A2 receptors, adenosine inhibits the upregulation of Mac-1 (Cd11b/CD18) expression on FMLP-stimulated neutrophils. Am J Respir Cell Mol Biol 9(2):179-185. doi:10.1165/ajrcmb/9.2.179

89. Cadieux JS, Leclerc P, St-Onge M, Dussault AA, Laflamme C, Picard S, Ledent C, Borgeat P, Pouliot M (2005) Potentiation of neutrophil cyclooxygenase-2 by adenosine: an early antiinflammatory signal. J Cell Sci 118(Pt 7):1437-1447. doi:10. $1242 /$ jcs. 01737

90. Sullivan GW, Linden J, Buster BL, Scheld WM (1999) Neutrophil A2A adenosine receptor inhibits inflammation in a rat model of meningitis: synergy with the type IV phosphodiesterase inhibitor, rolipram. J Infect Dis 180(5):1550-1560. doi:10.1086/315084

91. McColl SR, St-Onge M, Dussault AA, Laflamme C, Bouchard L, Boulanger J, Pouliot M (2006) Immunomodulatory impact of the A2A adenosine receptor on the profile of chemokines produced by neutrophils. FASEB J: Off Publ Fed Am Soc Exp Biol 20(1):187189. doi:10.1096/fj.05-4804fje

92. Krump E, Lemay G, Borgeat P (1996) Adenosine A2 receptorinduced inhibition of leukotriene B4 synthesis in whole blood ex vivo. Br J Pharmacol 117(8):1639-1644

93. Krump E, Picard S, Mancini J, Borgeat P (1997) Suppression of leukotriene B4 biosynthesis by endogenous adenosine in ligandactivated human neutrophils. J Exp Med 186(8):1401-1406 
94. Surette ME, Krump E, Picard S, Borgeat P (1999) Activation of leukotriene synthesis in human neutrophils by exogenous arachidonic acid: inhibition by adenosine $\mathrm{A}(2 \mathrm{a})$ receptor agonists and crucial role of autocrine activation by leukotriene B(4). Mol Pharmacol 56(5):1055-1062

95. Flamand N, Boudreault S, Picard S, Austin M, Surette ME, Plante H, Krump E, Vallee MJ, Gilbert C, Naccache P, Laviolette M, Borgeat P (2000) Adenosine, a potent natural suppressor of arachidonic acid release and leukotriene biosynthesis in human neutrophils. Am J Respir Crit Care Med 161(2 Pt 2):S88-S94. doi:10. 1164/ajrccm.161.supplement_1.ltta-18

96. Flamand N, Surette ME, Picard S, Bourgoin S, Borgeat P (2002) Cyclic AMP-mediated inhibition of 5-lipoxygenase translocation and leukotriene biosynthesis in human neutrophils. Mol Pharmacol 62(2):250-256

97. Sullivan GW, Rieger JM, Scheld WM, Macdonald TL, Linden J (2001) Cyclic AMP-dependent inhibition of human neutrophil oxidative activity by substituted 2-propynylcyclohexyl adenosine $\mathrm{A}(2 \mathrm{~A})$ receptor agonists. Br J Pharmacol 132(5):1017-1026. doi: 10.1038/sj.bjp.0703893

98. Anderson R, Visser SS, Ramafi G, Theron AJ (2000) Accelerated resequestration of cytosolic calcium and suppression of the proinflammatory activities of human neutrophils by CGS 21680 in vitro. Br J Pharmacol 130(4):717-724. doi:10.1038/sj.bjp. 0703344

99. Richter J (1992) Effect of adenosine analogues and cAMP-raising agents on TNF-, GM-CSF-, and chemotactic peptide-induced degranulation in single adherent neutrophils. J Leukoc Biol 51(3): 270-275

100. Visser SS, Theron AJ, Ramafi G, Ker JA, Anderson R (2000) Apparent involvement of the $\mathrm{A}(2 \mathrm{~A})$ subtype adenosine receptor in the anti-inflammatory interactions of CGS 21680 , cyclopentyladenosine, and IB-MECA with human neutrophils. Biochem Pharmacol 60(7):993-999

101. Walker BA, Rocchini C, Boone RH, Ip S, Jacobson MA (1997) Adenosine A2a receptor activation delays apoptosis in human neutrophils. J Immunol (Baltimore, Md : 1950) 158(6):2926-2931

102. Liu YW, Yang T, Zhao L, Ni Z, Yang N, He F, Dai SS (2016) Activation of adenosine $2 \mathrm{~A}$ receptor inhibits neutrophil apoptosis in an autophagy-dependent manner in mice with systemic inflammatory response syndrome. Sci Report 6:33614. doi:10.1038/ srep33614

103. Ryzhov S, Goldstein AE, Matafonov A, Zeng D, Biaggioni I, Feoktistov I (2004) Adenosine-activated mast cells induce IgE synthesis by B lymphocytes: an A2B-mediated process involving Th2 cytokines IL-4 and IL-13 with implications for asthma. J Immunol (Baltimore, Md : 1950) 172(12):7726-7733

104. Kreckler LM, Gizewski E, Wan TC, Auchampach JA (2009) Adenosine suppresses lipopolysaccharide-induced tumor necrosis factor-alpha production by murine macrophages through a protein kinase A and exchange protein activated by cAMP-independent signaling pathway. J Pharmacol Exp Ther 331(3):1051-1061. doi: 10.1124/jpet.109.157651

105. Hassanian SM, Dinarvand P, Rezaie AR (2014) Adenosine regulates the proinflammatory signaling function of thrombin in endothelial cells. J Cell Physiol 229(9):1292-1300. doi:10.1002/jcp. 24568

106. Zarek PE, Huang CT, Lutz ER, Kowalski J, Horton MR, Linden J, Drake CG, Powell JD (2008) A2A receptor signaling promotes peripheral tolerance by inducing T-cell anergy and the generation of adaptive regulatory T cells. Blood 111(1):251-259. doi:10. 1182/blood-2007-03-081646

107. Csoka B, Himer L, Selmeczy Z, Vizi ES, Pacher P, Ledent C, Deitch EA, Spolarics Z, Nemeth ZH, Hasko G (2008) Adenosine A2A receptor activation inhibits T helper 1 and $T$ helper 2 cell development and effector function. FASEB J: Off Publ
Fed Am Soc Exp Biol 22(10):3491-3499. doi:10.1096/fj.08107458

108. Alam MS, Kurtz CC, Wilson JM, Burnette BR, Wiznerowicz EB, Ross WG, Rieger JM, Figler RA, Linden J, Crowe SE, Ernst PB (2009) A2A adenosine receptor (AR) activation inhibits proinflammatory cytokine production by human CD4+ helper T cells and regulates Helicobacter-induced gastritis and bacterial persistence. Mucosal Immunol 2(3):232-242. doi:10.1038/mi.2009.4

109. Hasko G, Kuhel DG, Chen JF, Schwarzschild MA, Deitch EA, Mabley JG, Marton A, Szabo C (2000) Adenosine inhibits IL-12 and TNF-[alpha] production via adenosine A2a receptordependent and independent mechanisms. FASEB J: Off Publ Fed Am Soc Exp Biol 14(13):2065-2074. doi:10.1096/fj.990508com

110. Erdmann AA, Gao ZG, Jung U, Foley J, Borenstein T, Jacobson KA, Fowler DH (2005) Activation of Th1 and Tc1 cell adenosine A2A receptors directly inhibits IL-2 secretion in vitro and IL-2driven expansion in vivo. Blood 105(12):4707-4714. doi:10. 1182/blood-2004-04-1407

111. Lappas CM, Rieger JM, Linden J (2005) A2A adenosine receptor induction inhibits IFN-gamma production in murine CD4+ T cells. J Immunol (Baltimore, Md : 1950) 174(2):1073-1080

112. Ohta A, Kini R, Ohta A, Subramanian M, Madasu M, Sitkovsky $M$ (2012) The development and immunosuppressive functions of CD4(+) CD25(+) FoxP3(+) regulatory T cells are under influence of the adenosine-A2A adenosine receptor pathway. Front Immunol 3:190. doi:10.3389/fimmu.2012.00190

113. Huang X, He Y, Chen Y, Wu P, Gui D, Cai H, Chen A, Chen M, Dai C, Yao D, Wang L (2016) Baicalin attenuates bleomycininduced pulmonary fibrosis via adenosine $\mathrm{A} 2 \mathrm{a}$ receptor related TGF-beta1-induced ERK1/2 signaling pathway. BMC Pulm Med 16(1):132. doi:10.1186/s12890-016-0294-1

114. Barbera-Cremades M, Baroja-Mazo A, Pelegrin P (2016) Purinergic signaling during macrophage differentiation results in M2 alternative activated macrophages. J Leukoc Biol 99(2):289 299. doi:10.1189/jlb.1A0514-267RR

115. Csoka B, Selmeczy Z, Koscso B, Nemeth ZH, Pacher P, Murray PJ, Kepka-Lenhart D, Morris SM Jr, Gause WC, Leibovich SJ, Hasko G (2012) Adenosine promotes alternative macrophage activation via A2A and A2B receptors. FASEB J: Off Publ Fed Am Soc Exp Biol 26(1):376-386. doi:10.1096/fj.11-190934

116. Ferrante CJ, Pinhal-Enfield G, Elson G, Cronstein BN, Hasko G, Outram S, Leibovich SJ (2013) The adenosine-dependent angiogenic switch of macrophages to an M2-like phenotype is independent of interleukin-4 receptor alpha (IL-4Ralpha) signaling. Inflammation 36(4):921-931. doi:10.1007/s10753-013-9621-3

117. Koscso B, Csoka B, Kokai E, Nemeth ZH, Pacher P, Virag L, Leibovich SJ, Hasko G (2013) Adenosine augments IL-10induced STAT3 signaling in M2c macrophages. J Leukoc Biol 94(6):1309-1315. doi:10.1189/jlb.0113043

118. Hasko G, Pacher P (2012) Regulation of macrophage function by adenosine. Arterioscler Thromb Vasc Biol 32(4):865-869. doi:10. 1161/atvbaha.111.226852

119. Koroskenyi K, Kiss B, Szondy Z (2016) Adenosine A2A receptor signaling attenuates LPS-induced pro-inflammatory cytokine formation of mouse macrophages by inducing the expression of DUSP1. Biochimica et biophysica acta 1863 (7 Pt A):14611471. doi:10.1016/j.bbamcr.2016.04.003

120. Majumdar S, Aggarwal BB (2003) Adenosine suppresses activation of nuclear factor-kappaB selectively induced by tumor necrosis factor in different cell types. Oncogene 22(8):1206-1218. doi: 10.1038/sj.onc. 1206184

121. Mirakaj V, Thix CA, Laucher S, Mielke C, Morote-Garcia JC, Schmit MA, Henes J, Unertl KE, Kohler D, Rosenberger P (2010) Netrin-1 dampens pulmonary inflammation during acute 
lung injury. Am J Respir Crit Care Med 181(8):815-824. doi:10. 1164/rccm.200905-07170C

122. Aherne CM, Collins CB, Masterson JC, Tizzano M, Boyle TA, Westrich JA, Parnes JA, Furuta GT, Rivera-Nieves J, Eltzschig HK (2012) Neuronal guidance molecule netrin-1 attenuates inflammatory cell trafficking during acute experimental colitis. Gut 61(5):695-705. doi:10.1136/gutjnl-2011-300012

123. van der Hoeven D, Wan TC, Gizewski ET, Kreckler LM, Maas JE, Van Orman J, Ravid K, Auchampach JA (2011) A role for the lowaffinity $\mathrm{A} 2 \mathrm{~B}$ adenosine receptor in regulating superoxide generation by murine neutrophils. J Pharmacol Exp Ther 338(3):1004 1012. doi:10.1124/jpet.111.181792

124. Nemeth ZH, Lutz CS, Csoka B, Deitch EA, Leibovich SJ, Gause WC, Tone M, Pacher P, Vizi ES, Hasko G (2005) Adenosine augments IL-10 production by macrophages through an A2B receptor-mediated posttranscriptional mechanism. J Immunol (Baltimore, Md: 1950) 175(12):8260-8270

125. Novitskiy SV, Ryzhov S, Zaynagetdinov R, Goldstein AE, Huang Y, Tikhomirov OY, Blackburn MR, Biaggioni I, Carbone DP, Feoktistov I, Dikov MM (2008) Adenosine receptors in regulation of dendritic cell differentiation and function. Blood 112(5):18221831. doi:10.1182/blood-2008-02-136325

126. Wilson JM, Kurtz CC, Black SG, Ross WG, Alam MS, Linden J, Ernst PB (2011) The A2B adenosine receptor promotes Th17 differentiation via stimulation of dendritic cell IL-6. J Immunol (Baltimore, Md: 1950) 186(12):6746-6752. doi:10.4049/ jimmunol.1100117

127. Liang D, Zuo A, Shao H, Chen M, Kaplan HJ, Sun D (2015) A2B adenosine receptor activation switches differentiation of bone marrow cells to a CD11 c(+)Gr-1(+) dendritic cell subset that promotes the Th17 response. Immun Inflammation Dis 3(4):360-373. doi: 10.1002/iid3.74

128. Karmouty-Quintana H, Philip K, Acero LF, Chen NY, Weng T, Molina JG, Luo F, Davies J, Le NB, Bunge I, Volcik KA, Le TT, Johnston RA, Xia Y, Eltzschig HK, Blackburn MR (2015) Deletion of ADORA2B from myeloid cells dampens lung fibrosis and pulmonary hypertension. FASEB J: Off Publ Fed Am Soc Exp Biol 29(1):50-60. doi:10.1096/fj.14-260182

129. Eckle T, Grenz A, Laucher S, Eltzschig HK (2008) A2B adenosine receptor signaling attenuates acute lung injury by enhancing alveolar fluid clearance in mice. J Clin Invest 118(10):3301-3315

130. Grant MB, Tarnuzzer RW, Caballero S, Ozeck MJ, Davis MI, Spoerri PE, Feoktistov I, Biaggioni I, Shryock JC, Belardinelli L (1999) Adenosine receptor activation induces vascular endothelial growth factor in human retinal endothelial cells. Circ Res 85(8): 699-706

131. Zhong H, Wu Y, Belardinelli L, Zeng D (2006) A2B adenosine receptors induce IL-19 from bronchial epithelial cells, resulting in TNF-alpha increase. Am J Respir Cell Mol Biol 35(5):587-592. doi:10.1165/rcmb.2005-0476OC

132. Wilkinson PF, Farrell FX, Morel D, Law W, Murphy S (2016) Adenosine signaling increases proinflammatory and profibrotic mediators through activation of a functional adenosine $2 \mathrm{~B}$ receptor in renal fibroblasts. Ann Clin Lab Sci 46(4):339-345

133. Feoktistov I, Ryzhov S, Goldstein AE, Biaggioni I (2003) Mast cell-mediated stimulation of angiogenesis: cooperative interaction between A2B and A3 adenosine receptors. Circ Res 92(5):485492. doi:10.1161/01.res.0000061572.10929.2d

134 Chen Y, Corriden R, Inoue Y, Yip L, Hashiguchi N, Zinkernagel A, Nizet V, Insel PA, Junger WG (2006) ATP release guides neutrophil chemotaxis via P2Y2 and A3 receptors. Science 314(5806): 1792-1795

135. Inoue Y, Chen Y, Hirsh MI, Yip L, Junger WG (2008) A3 and $\mathrm{P} 2 \mathrm{Y} 2$ receptors control the recruitment of neutrophils to the lungs in a mouse model of sepsis. Shock (Augusta, Ga) 30(2):173-177. doi:10.1097/shk.0b013e318160dad4
136. Tweedy L, Knecht DA, Mackay GM, Insall RH (2016) Selfgenerated chemoattractant gradients: attractant depletion extends the range and robustness of chemotaxis. PLoS Biol 14(3): e1002404. doi:10.1371/journal.pbio.1002404

137. Tweedy L, Susanto O, Insall RH (2016) Self-generated chemotactic gradients-cells steering themselves. Curr Opin Cell Biol 42:4651. doi:10.1016/j.ceb.2016.04.003

138. Dona E, Barry JD, Valentin G, Quirin C, Khmelinskii A, Kunze A, Durdu S, Newton LR, Fernandez-Minan A, Huber W, Knop M, Gilmour D (2013) Directional tissue migration through a selfgenerated chemokine gradient. Nature 503(7475):285-289. doi: 10.1038 /nature 12635

139. So H (2016) Where to go: breaking the symmetry in cell motility. PLoS Biol 14(5):e1002463. doi:10.1371/journal.pbio.1002463

140. Moissoglu K, Majumdar R, Parent CA (2014) Cell migration: sinking in a gradient. Curr Biol: CB 24(1):R23-R25. doi:10. 1016/j.cub.2013.10.075

141. Joos G, Jakim J, Kiss B, Szamosi R, Papp T, Felszeghy S, Saghy T, Nagy G, Szondy Z (2017) Involvement of adenosine A3 receptors in the chemotactic navigation of macrophages towards apoptotic cells. Immunol Lett 183:62-72. doi:10.1016/j.imlet.2017. 02.002

142. Lee JY, Jhun BS, Oh YT, Lee JH, Choe W, Baik HH, Ha J, Yoon KS, Kim SS, Kang I (2006) Activation of adenosine A3 receptor suppresses lipopolysaccharide-induced TNF-alpha production through inhibition of PI 3-kinase/Akt and NF-kappaB activation in murine BV2 microglial cells. Neurosci Lett 396(1):1-6. doi:10. 1016/j.neulet.2005.11.004

143. Ren T, Qiu Y, Wu W, Feng X, Ye S, Wang Z, Tian T, He Y, Yu C, Zhou Y (2014) Activation of adenosine A3 receptor alleviates TNF-alpha-induced inflammation through inhibition of the NFkappaB signaling pathway in human colonic epithelial cells. Mediat Inflamm 2014:818251. doi:10.1155/2014/818251

144. Hoskin DW, Butler JJ, Drapeau D, Haeryfar SM, Blay J (2002) Adenosine acts through an $\mathrm{A} 3$ receptor to prevent the induction of murine anti-CD3-activated killer T cells. Int J Cancer 99(3):386395. doi:10.1002/ijc. 10325

145. Morschl E, Molina JG, Volmer JB, Mohsenin A, Pero RS, Hong JS, Kheradmand F, Lee JJ, Blackburn MR (2008) A3 adenosine receptor signaling influences pulmonary inflammation and fibrosis. Am J Respir Cell Mol Biol 39(6):697-705. doi:10.1165/rcmb. 2007-0419OC

146. Oury C, Lecut C, Hego A, Wera O, Delierneux C (2015) Purinergic control of inflammation and thrombosis: role of P2X1 receptors. Comput Struct Biotechnol J 13:106-110. doi: 10.1016/j.csbj.2014.11.008

147. Woehrle T, Yip L, Elkhal A, Sumi Y, Chen Y, Yao Y, Insel PA, Junger WG (2010) Pannexin-1 hemichannel-mediated ATP release together with $\mathrm{P} 2 \mathrm{X} 1$ and $\mathrm{P} 2 \mathrm{X} 4$ receptors regulate T-cell activation at the immune synapse. Blood 116(18):3475-3484. doi:10. 1182/blood-2010-04-277707

148. Bulanova E, Budagian V, Orinska Z, Koch-Nolte F, Haag F, Bulfone-Paus S (2009) ATP induces P2X7 receptor-independent cytokine and chemokine expression through $\mathrm{P} 2 \mathrm{X} 1$ and $\mathrm{P} 2 \mathrm{X} 3$ receptors in murine mast cells (article retracted in 2011 due to figure irregularities). J Leukoc Biol 85(4):692-702. doi:10.1189/jlb. 0808470

149. Manohar M, Hirsh MI, Chen Y, Woehrle T, Karande AA, Junger WG (2012) ATP release and autocrine signaling through P2X4 receptors regulate gammadelta $\mathrm{T}$ cell activation. J Leukoc Biol 92(4):787-794. doi:10.1189/jlb.0312121

150. Vazquez-Villoldo N, Domercq M, Martin A, Llop J, GomezVallejo V, Matute C (2014) P2X4 receptors control the fate and survival of activated microglia. Glia 62(2):171-184. doi:10.1002/ glia.22596 
151. Lee BH, Hwang DM, Palaniyar N, Grinstein S, Philpott DJ, Hu J (2012) Activation of P2X(7) receptor by ATP plays an important role in regulating inflammatory responses during acute viral infection. PLoS One 7(4):e35812. doi:10.1371/journal.pone.0035812

152. Jo EK, Kim JK, Shin DM, Sasakawa C (2016) Molecular mechanisms regulating NLRP3 inflammasome activation. Cell Mol Immunol 13(2):148-159

153. Latz E, Xiao TS, Stutz A (2013) Activation and regulation of the inflammasomes. Nat Rev Immunol 13(6):397-411. doi:10.1038/ nri3452

154. Sakaki H, Fujiwaki T, Tsukimoto M, Kawano A, Harada H, Kojima S (2013) P2X4 receptor regulates P2X7 receptordependent IL-1beta and IL-18 release in mouse bone marrowderived dendritic cells. Biochem Biophys Res Commun 432(3): 406-411. doi:10.1016/j.bbrc.2013.01.135

155. Luna-Gomes T, Santana PT, Coutinho-Silva R (2015) Silicainduced inflammasome activation in macrophages: role of ATP and P2X7 receptor. Immunobiology 220(9):1101-1106. doi:10. 1016/j.imbio.2015.05.004

156. Karmakar M, Katsnelson MA, Dubyak GR, Pearlman E (2016) Neutrophil P2X7 receptors mediate NLRP3 inflammasomedependent IL-1beta secretion in response to ATP. Nat Commun 7:10555. doi:10.1038/ncomms 10555

157. Eleftheriadis T, Pissas G, Karioti A, Antoniadi G, Golfinopoulos S, Liakopoulos V, Mamara A, Speletas M, Koukoulis G, Stefanidis I (2013) Uric acid induces caspase-1 activation, IL1 beta secretion and $\mathrm{P} 2 \mathrm{X} 7$ receptor dependent proliferation in primary human lymphocytes. Hippokratia 17(2):141-145

158. Tsukimoto M, Maehata M, Harada H, Ikari A, Takagi K, Degawa $\mathrm{M}$ (2006) P2X7 receptor-dependent cell death is modulated during murine $\mathrm{T}$ cell maturation and mediated by dual signaling pathways. J Immunol (Baltimore, Md : 1950) 177(5):2842-2850

159. Aswad F, Dennert G (2006) P2X7 receptor expression levels determine lethal effects of a purine based danger signal in T lymphocytes. Cell Immunol 243(1):58-65. doi:10.1016/j.cellimm.2006. 12.003

160. Scheuplein F, Schwarz N, Adriouch S, Krebs C, Bannas P, Rissiek B, Seman M, Haag F, Koch-Nolte F (2009) NAD+ and ATP released from injured cells induce P2X7-dependent shedding of CD62L and externalization of phosphatidylserine by murine T cells. J Immunol (Baltimore, Md : 1950) 182(5):2898-2908. doi: 10.4049/jimmunol.0801711

161. Kawano A, Tsukimoto M, Noguchi T, Hotta N, Harada H, Takenouchi T, Kitani H, Kojima S (2012) Involvement of P2X4 receptor in $\mathrm{P} 2 \mathrm{X} 7$ receptor-dependent cell death of mouse macrophages. Biochem Biophys Res Commun 419(2):374-380. doi:10. 1016/j.bbrc.2012.01.156

162. Gu BJ, Wiley JS (2006) Rapid ATP-induced release of matrix metalloproteinase 9 is mediated by the $\mathrm{P} 2 \mathrm{X} 7$ receptor. Blood 107(12):4946-4953. doi:10.1182/blood-2005-07-2994

163. de Torre-Minguela C, Barbera-Cremades M, Gomez AI, MartinSanchez F, Pelegrin P (2016) Macrophage activation and polarization modify P2X7 receptor secretome influencing the inflammatory process. Sci Report 6:22586. doi:10.1038/srep22586

164. Csoka B, Nemeth ZH, Toro G, Idzko M, Zech A, Koscso B, Spolarics Z, Antonioli L, Cseri K, Erdelyi K, Pacher P, Hasko G (2015) Extracellular ATP protects against sepsis through macrophage $\mathrm{P} 2 \mathrm{X} 7$ purinergic receptors by enhancing intracellular bacterial killing. FASEB J: Off Publ Fed Am Soc Exp Biol 29(9): 3626-3637. doi:10.1096/fj.15-272450

165. Wareham KJ, Seward EP (2016) P2X7 receptors induce degranulation in human mast cells. Purinergic Signal 12(2):235-246. doi: 10.1007/s11302-016-9497-4

166. Kawamura H, Aswad F, Minagawa M, Govindarajan S, Dennert $\mathrm{G}$ (2006) P2X7 receptors regulate NKT cells in autoimmune hepatitis. J Immunol (Baltimore, Md : 1950) 176(4):2152-2160
167. Pupovac A, Foster CM, Sluyter R (2013) Human P2X7 receptor activation induces the rapid shedding of CXCL16. Biochem Biophys Res Commun 432(4):626-631. doi:10.1016/j.bbrc. 2013.01.134

168. Pupovac A, Geraghty NJ, Watson D, Sluyter R (2015) Activation of the $\mathrm{P} 2 \mathrm{X} 7$ receptor induces the rapid shedding of $\mathrm{CD} 23$ from human and murine B cells. Immunol Cell Biol 93(1):77-85. doi: 10.1038/icb.2014.69

169. Huang SW, Walker C, Pennock J, Else K, Muller W, Daniels MJ, Pellegrini C, Brough D, Lopez-Castejon G, Cruickshank SM (2016) P2X7 receptor-dependent tuning of gut epithelial responses to infection. Immunol Cell BiolImmunology and cell biology. doi: 10.1038/icb.2016.75

170. Yip L, Woehrle T, Corriden R, Hirsh M, Chen Y, Inoue Y, Ferrari V, Insel PA, Junger WG (2009) Autocrine regulation of T-cell activation by ATP release and P2X7 receptors. FASEB J: Off Publ Fed Am Soc Exp Biol 23(6):1685-1693. doi:10.1096/fj.08126458

171. Proietti M, Cornacchione V, Rezzonico Jost T, Romagnani A, Faliti CE, Perruzza L, Rigoni R, Radaelli E, Caprioli F, Preziuso S, Brannetti B, Thelen M, McCoy KD, Slack E, Traggiai E, Grassi F (2014) ATP-gated ionotropic P2X7 receptor controls follicular T helper cell numbers in Peyer's patches to promote host-microbiota mutualism. Immunity 41(5):789-801. doi:10.1016/j.immuni. 2014.10.010

172. Hubert S, Rissiek B, Klages K, Huehn J, Sparwasser T, Haag F, Koch-Nolte F, Boyer O, Seman M, Adriouch S (2010) Extracellular NAD+ shapes the Foxp3+ regulatory T cell compartment through the ART2-P2X7 pathway. J Exp Med 207(12): 2561-2568. doi:10.1084/jem.20091154

173. Wilhelm K, Ganesan J, Muller T, Durr C, Grimm M, Beilhack A, Krempl CD, Sorichter S, Gerlach UV, Juttner E, Zerweck A, Gartner F, Pellegatti P, Di Virgilio F, Ferrari D, Kambham N, Fisch P, Finke J, Idzko M, Zeiser R (2010) Graft-versus-host disease is enhanced by extracellular ATP activating P2X7R. Nat Med 16(12):1434-1438. doi:10.1038/nm.2242

174. Mishra A, Guo Y, Zhang L, More S, Weng T, Chintagari NR, Huang C, Liang Y, Pushparaj S, Gou D, Breshears M, Liu L (2016) A critical role for P2X7 receptor-induced VCAM-1 shedding and neutrophil infiltration during acute lung injury. $\mathrm{J}$ Immunol

175. Wang CM, Chang YY, Sun SH (2003) Activation of P2X7 purinoceptor-stimulated TGF-beta $1 \mathrm{mRNA}$ expression involves $\mathrm{PKC} / \mathrm{MAPK}$ signalling pathway in a rat brain-derived type-2 astrocyte cell line, RBA-2. Cell Signal 15(12):1129-1137

176. Qu LP, Xue H, Yuan P, Zhou L, Yao T, Huang Y, Lu LM (2009) Adenosine 5'-triphosphate stimulates the increase of TGF-beta1 in rat mesangial cells under high-glucose conditions via reactive oxygen species and ERK1/2. Acta Pharmacol Sin 30(12):16011606. doi:10.1038/aps.2009.155

177. Nylander S, Mattsson C, Ramstrom S, Lindahl TL (2004) Synergistic action between inhibition of P2Y12/P2Y1 and $\mathrm{P} 2 \mathrm{Y} 12 /$ thrombin in ADP- and thrombin-induced human platelet activation. Br J Pharmacol 142(8):1325-1331. doi:10.1038/sj.bjp. 0705885

178. Muller T, Fay S, Vieira RP, Karmouty-Quintana H, Cicko S, Ayata K, Zissel G, Goldmann T, Lungarella G, Ferrari D, Di Virgilio F, Robaye B, Boeynaems JM, Blackburn MR, Idzko M (2017) The purinergic receptor subtype $\mathrm{P} 2 \mathrm{Y} 2$ mediates chemotaxis of neutrophils and fibroblasts in fibrotic lung disease. Oncotarget. doi:10. 18632/oncotarget. 16414

179. Muller T, Robaye B, Vieira RP, Ferrari D, Grimm M, Jakob T, Martin SF, Di Virgilio F, Boeynaems JM, Virchow JC, Idzko M (2010) The purinergic receptor P2Y2 receptor mediates chemotaxis of dendritic cells and eosinophils in allergic lung 
inflammation. Allergy 65(12):1545-1553. doi:10.1111/j.13989995.2010.02426.x

180. Vanderstocken G, Bondue B, Horckmans M, Di Pietrantonio L, Robaye B, Boeynaems JM, Communi D (2010) P2Y2 receptor regulates VCAM-1 membrane and soluble forms and eosinophil accumulation during lung inflammation. J Immunol (Baltimore, Md: 1950) 185(6):3702-3707. doi:10.4049/jimmunol.0903908

181. Ohsawa K, Irino Y, Nakamura Y, Akazawa C, Inoue K, Kohsaka S (2007) Involvement of P2X4 and P2Y12 receptors in ATP-induced microglial chemotaxis. Glia 55(6):604-616. doi:10.1002/glia.20489

182. Irino Y, Nakamura Y, Inoue K, Kohsaka S, Ohsawa K (2008) Akt activation is involved in P2Y12 receptor-mediated chemotaxis of microglia. J Neurosci Res 86(7):1511-1519. doi:10.1002/jnr.21610

183. Sil P, Hayes CP, Reaves BJ, Breen P, Quinn S, Sokolove J, Rada B (2017) P2Y6 receptor antagonist MRS2578 inhibits neutrophil activation and aggregated neutrophil extracellular trap formation induced by gout-associated monosodium urate crystals. J Immunol (Baltimore, Md: 1950) 198(1):428-442. doi:10.4049/ jimmunol.1600766

184. Uratsuji H, Tada Y, Kawashima T, Kamata M, Hau CS, Asano Y, Sugaya M, Kadono T, Asahina A, Sato S, Tamaki K (2012) P2Y6 receptor signaling pathway mediates inflammatory responses induced by monosodium urate crystals. J Immunol (Baltimore, Md: 1950) 188(1):436-444. doi:10.4049/jimmunol.1003746

185. Kimura T, Kobayashi S, Hanihara-Tatsuzawa F, Sayama A, MaruYama T, Muta T (2014) Responses of macrophages to the danger signals released from necrotic cells. Int Immunol 26(12): 697-704. doi:10.1093/intimm/dxu080

186. Inoue K (2007) UDP facilitates microglial phagocytosis through P2Y6 receptors. Cell Adhes Migr 1(3):131-132

187. Morioka N, Tokuhara M, Harano S, Nakamura Y, HisaokaNakashima K, Nakata Y (2013) The activation of P2Y6 receptor in cultured spinal microglia induces the production of CCL2 through the MAP kinases-NF-kappaB pathway. Neuropharmacology 75:116-125. doi:10.1016/j.neuropharm. 2013.07.017

188. Xu Y, Hu W, Liu Y, Xu P, Li Z, Wu R, Shi X, Tang Y (2016) P2Y6 receptor-mediated microglial phagocytosis in radiation-induced brain injury. Mol Neurobiol 53(6):3552-3564. doi:10.1007/ s12035-015-9282-3

189. Zhu J, Wang Z, Zhang N, Ma J, Xu SL, Wang Y, Shen Y, Li YH (2016) Protein interacting C-kinase 1 modulates surface expression of $\mathrm{P} 2 \mathrm{Y} 6$ purinoreceptor, actin polymerization and phagocytosis in microglia. Neurochem Res 41(4):795-803. doi:10.1007/ s11064-015-1754-3

190. Nakano M, Ito K, Yuno T, Soma N, Aburakawa S, Kasai K, Nakamura T, Takami H (2017) UDP/P2Y6 receptor signaling regulates IgE-dependent degranulation in human basophils. Allergol Int: Off J Jpn Soc Allergol. doi:10.1016/j.alit.2017.02.014

191. Khine AA, Del Sorbo L, Vaschetto R, Voglis S, Tullis E, Slutsky AS, Downey GP, Zhang H (2006) Human neutrophil peptides induce interleukin- 8 production through the $\mathrm{P} 2 \mathrm{Y} 6$ signaling pathway. Blood 107(7):2936-2942. doi:10.1182/blood-2005-06-2314

192. Grbic DM, Degagne E, Larrivee JF, Bilodeau MS, Vinette V, Arguin G, Stankova J, Gendron FP (2012) P2Y6 receptor contributes to neutrophil recruitment to inflamed intestinal mucosa by increasing CXC chemokine ligand 8 expression in an AP-1dependent manner in epithelial cells. Inflamm Bowel Dis 18(8): 1456-1469. doi:10.1002/ibd.21931

193. Li R, Tan B, Yan Y, Ma X, Zhang N, Zhang Z, Liu M, Qian M, Du B (2014) Extracellular UDP and P2Y6 function as a danger signal to protect mice from vesicular stomatitis virus infection through an increase in IFN-beta production. J Immunol (Baltimore, Md : 1950) 193(9):4515-4526. doi:10.4049/jimmunol.1301930

194. Vaughan KR, Stokes L, Prince LR, Marriott HM, Meis S, Kassack MU, Bingle CD, Sabroe I, Surprenant A, Whyte MK (2007)
Inhibition of neutrophil apoptosis by ATP is mediated by the P2Y11 receptor. J Immunol (Baltimore, Md : 1950) 179(12):8544-8553

195. Alkayed F, Kashimata M, Koyama N, Hayashi T, Tamura Y, Azuma Y (2012) P2Y11 purinoceptor mediates the ATPenhanced chemotactic response of rat neutrophils. J Pharmacol Sci 120(4):288-295

196. van der Weyden L, Conigrave AD, Morris MB (2000) Signal transduction and white cell maturation via extracellular ATP and the P2Y11 receptor. Immunol Cell Biol 78(4):369-374. doi:10. 1046/j.1440-1711.2000.00918.x

197. Wilkin F, Duhant X, Bruyns C, Suarez-Huerta N, Boeynaems JM, Robaye B (2001) The P2Y11 receptor mediates the ATP-induced maturation of human monocyte-derived dendritic cells. J Immunol (Baltimore, Md : 1950) 166(12):7172-7177

198. Schnurr M, Toy T, Stoitzner P, Cameron P, Shin A, Beecroft T, Davis ID, Cebon J, Maraskovsky E (2003) ATP gradients inhibit the migratory capacity of specific human dendritic cell types: implications for P2Y11 receptor signaling. Blood 102(2):613-620. doi:10.1182/blood-2002-12-3745

199. Meis S, Hamacher A, Hongwiset D, Marzian C, Wiese M, Eckstein N, Royer HD, Communi D, Boeynaems JM, Hausmann R, Schmalzing G, Kassack MU (2010) NF546 [4,4'(carbonylbis(imino-3,1-phenylene-carbonylimino-3,1-(4-methylphenylene)-car bonylimino))-bis(1,3-xylene-alpha,alpha'-diphosphonic acid) tetrasodium salt] is a non-nucleotide P2Y11 agonist and stimulates release of interleukin- 8 from human monocytederived dendritic cells. J Pharmacol Exp Ther 332(1):238-247. doi:10.1124/jpet.109.157750

200. Sakaki H, Tsukimoto M, Harada H, Moriyama Y, Kojima S (2013) Autocrine regulation of macrophage activation via exocytosis of ATP and activation of P2Y11 receptor. PLoS One 8(4):e59778. doi:10.1371/journal.pone.0059778

201. Satonaka H, Nagata D, Takahashi M, Kiyosue A, Myojo M, Fujita D, Ishimitsu T, Nagano T, Nagai R, Hirata Y (2015) Involvement of $\mathrm{P} 2 \mathrm{Y} 12$ receptor in vascular smooth muscle inflammatory changes via MCP-1 upregulation and monocyte adhesion. Am J Phys Heart Circ Phys 308(8):H853-H861. doi:10.1152/ajpheart.00862.2013

202. Ben Addi A, Cammarata D, Conley PB, Boeynaems JM, Robaye B (2010) Role of the P2Y12 receptor in the modulation of murine dendritic cell function by ADP. J Immunol (Baltimore, Md: 1950) 185(10):5900-5906. doi:10.4049/jimmunol.0901799

203. Lou N, Takano T, Pei Y, Xavier AL, Goldman SA, Nedergaard M (2016) Purinergic receptor P2RY12-dependent microglial closure of the injured blood-brain barrier. Proc Natl Acad Sci U S A 113(4):1074-1079. doi:10.1073/pnas.1520398113

204. Haynes SE, Hollopeter G, Yang G, Kurpius D, Dailey ME, Gan WB, Julius D (2006) The P2Y12 receptor regulates microglial activation by extracellular nucleotides. Nat Neurosci 9(12): 1512-1519. doi:10.1038/nn1805

205. Moore CS, Ase AR, Kinsara A, Rao VT, Michell-Robinson M, Leong SY, Butovsky O, Ludwin SK, Seguela P, Bar-Or A, Antel JP (2015) P2Y12 expression and function in alternatively activated human microglia. Neurol(R) Neuroimmunol Neuroinflammation 2(2):e80. doi:10.1212/nxi.0000000000000080

206. Tozaki-Saitoh H, Miyata H, Yamashita T, Matsushita K, Tsuda M, Inoue K (2017) P2Y12 receptors in primary microglia activate nuclear factor of activated T-cell signaling to induce $\mathrm{C}-\mathrm{C}$ chemokine 3 expression. J Neurochem 141(1):100-110. doi:10.1111/jnc.13968

207. Wang L, Olivecrona G, Götberg M, Olsson ML, Winzell MS, Erlinge D (2005) ADP acting on P2Y13 receptors is a negative feedback pathway for ATP release from human red blood cells. Circ Res 96(2):189-196. doi:10.1161/01.res.0000153670.07559.e4

208. Arase T, Uchida H, Kajitani T, Ono M, Tamaki K, Oda H, Nishikawa S, Kagami M, Nagashima T, Masuda H, Asada H, Yoshimura Y, Maruyama T (2009) The UDP-glucose receptor P2RY14 triggers innate mucosal immunity in the female 
reproductive tract by inducing IL-8. J Immunol (Baltimore, Md : 1950) 182(11):7074-7084. doi:10.4049/jimmunol.0900001

209. Barrett MO, Sesma JI, Ball CB, Jayasekara PS, Jacobson KA, Lazarowski ER, Harden TK (2013) A selective high-affinity antagonist of the P2Y14 receptor inhibits UDP-glucose-stimulated chemotaxis of human neutrophils. Mol Pharmacol 84(1):41-49. doi:10.1124/mol.113.085654

210. Burnstock G, Boeynaems JM (2014) Purinergic signalling and immune cells. Purinergic Signal 10(4):529-564. doi:10.1007/ s11302-014-9427-2

211. Surprenant A, Rassendren F, Kawashima E, North RA, Buell G (1996) The cytolytic P2Z receptor for extracellular ATP identified as a $\mathrm{P} 2 \mathrm{X}$ receptor (P2X7). Science 272(5262):735-738

212. Eckle T, Fullbier L, Wehrmann M, Khoury J, Mittelbronn M, Ibla J, Rosenberger P, Eltzschig HK (2007) Identification of ectonucleotidases CD39 and CD73 in innate protection during acute lung injury. J Immunol 178(12):8127-8137

213. Matsuyama H, Amaya F, Hashimoto S, Ueno H, Beppu S, Mizuta M, Shime N, Ishizaka A, Hashimoto S (2008) Acute lung inflammation and ventilator-induced lung injury caused by ATP via the P2Y receptors: an experimental study. Respir Res 9:79

214. Csoka B, Nemeth ZH, Toro G, Koscso B, Kokai E, Robson SC, Enjyoji K, Rolandelli RH, Erdelyi K, Pacher P, Hasko G (2015) CD39 improves survival in microbial sepsis by attenuating systemic inflammation. FASEB J: Off Publ Fed Am Soc Exp Biol 29(1):25-36. doi:10.1096/fj.14-253567

215. Coddou C, Stojilkovic SS, Huidobro-Toro JP (2011) Allosteric modulation of ATP-gated P2X receptor channels. Rev Neurosci 22(3):335-354. doi:10.1515/rns.2011.014

216. Short KR, Kroeze EJ, Fouchier RA, Kuiken T (2014) Pathogenesis of influenza-induced acute respiratory distress syndrome. Lancet Infect Dis 14(1):57-69. doi:10.1016/s14733099(13)70286-X

217. Chen XJ, Seth S, Yue G, Kamat P, Compans RW, Guidot D, Brown LA, Eaton DC, Jain L (2004) Influenza virus inhibits $\mathrm{ENaC}$ and lung fluid clearance. Am J Physiol Lung Cell Mol Physiol 287(2):L366-L373. doi:10.1152/ajplung.00011.2004

218. Aeffner F, Bratasz A, Flano E, Powell KA, Davis IC (2012) Postinfection A77-1726 treatment improves cardiopulmonary function in H1N1 influenza-infected mice. Am J Respir Cell Mol Biol 47(4):543-551. doi:10.1165/rcmb.2012-0112OC

219. Wolk KE, Lazarowski ER, Traylor ZP, Yu EN, Jewell NA, Durbin RK, Durbin JE, Davis IC (2008) Influenza a virus inhibits alveolar fluid clearance in BALB/c mice. Am J Respir Crit Care Med 178(9):969-976. doi:10.1164/rccm.200803-455OC

220. Kunzelmann K, Sun J, Meanger J, King NJ, Cook DI (2007) Inhibition of airway $\mathrm{Na}+$ transport by respiratory syncytial virus. J Virol 81(8):3714-3720. doi:10.1128/jvi.02621-06

221. Chen L, Song W, Davis IC, Shrestha K, Schwiebert E, Sullender WM, Matalon S (2009) Inhibition of Na+ transport in lung epithelial cells by respiratory syncytial virus infection. Am J Respir Cell Mol Biol 40(5):588-600. doi:10.1165/rcmb.2008-0034OC

222. Kunzelmann K, Konig J, Sun J, Markovich D, King NJ, Karupiah G, Young JA, Cook DI (2004) Acute effects of parainfluenza virus on epithelial electrolyte transport. J Biol Chem 279(47):48760 48766. doi:10.1074/jbc.M409747200

223. Shen BQ, Finkbeiner WE, Wine JJ, Mrsny RJ, Widdicombe JH (1994) Calu-3: a human airway epithelial cell line that shows cAMP-dependent Cl- secretion. Am J Phys 266(5 Pt 1):L493-L501

224. Airas L, Niemela J, Yegutkin G, Jalkanen S (2007) Mechanism of action of IFN-beta in the treatment of multiple sclerosis: a special reference to CD73 and adenosine. Ann N Y Acad Sci 1110:641648. doi:10.1196/annals.1423.067

225. Niemela J, Ifergan I, Yegutkin GG, Jalkanen S, Prat A, Airas L (2008) IFN-beta regulates CD73 and adenosine expression at the blood-brain barrier. Eur J Immunol 38(10):2718-2726. doi:10. 1002/eji.200838437

226. Kiss J, Yegutkin GG, Koskinen K, Savunen T, Jalkanen S, Salmi M (2007) IFN-beta protects from vascular leakage via upregulation of CD73. Eur J Immunol 37(12):3334-3338. doi:10. 1002/eji.200737793

227. Vignali DA, Collison LW, Workman CJ (2008) How regulatory T cells work. Nat Rev Immunol 8(7):523-532

228. Bauernfeind F, Bartok E, Rieger A, Franchi L, Nunez G, Hornung V (2011) Cutting edge: reactive oxygen species inhibitors block priming, but not activation, of the NLRP3 inflammasome. J Immunol 187(2):613-617

229. Schroder K, Tschopp J (2010) The inflammasomes. Cell 140(6): 821-832

230. Belete HA, Hubmayr RD, Wang S, Singh RD (2011) The role of purinergic signaling on deformation induced injury and repair responses of alveolar epithelial cells. PLoS One 6(11):e27469. doi: 10.1371/journal.pone.0027469

231. Protti A, Cressoni M, Santini A, Langer T, Mietto C, Febres D, Chierichetti M, Coppola S, Conte G, Gatti S, Leopardi O, Masson S, Lombardi L, Lazzerini M, Rampoldi E, Cadringher P, Gattinoni L (2011) Lung stress and strain during mechanical ventilation: any safe threshold? Am J Respir Crit Care Med 183(10):1354-1362. doi:10.1164/rccm.201010-1757OC

232. Bellingan G, Maksimow M, Howell DC, Stotz M, Beale R, Beatty M, Walsh T, Binning A, Davidson A, Kuper M, Shah S, Cooper J, Waris M, Yegutkin GG, Jalkanen J, Salmi M, Piippo I, Jalkanen M, Montgomery H, Jalkanen S (2014) The effect of intravenous interferon-beta-1a (FP-1201) on lung CD73 expression and on acute respiratory distress syndrome mortality: an open-label study. Lancet Respir Med 2(2):98-107. doi:10.1016/s2213-2600(13)70259-5

233. Chunn JL, Molina JG, Mi T, Xia Y, Kellems RE, Blackburn MR (2005) Adenosine-dependent pulmonary fibrosis in adenosine deaminase-deficient mice. J Immunol (Baltimore, Md : 1950) 175(3):1937-1946

234. Chunn JL, Mohsenin A, Young HW, Lee CG, Elias JA, Kellems RE, Blackburn MR (2006) Partially adenosine deaminasedeficient mice develop pulmonary fibrosis in association with adenosine elevations. Am J Physiol Lung Cell Mol Physiol 290(3):L579-L587. doi:10.1152/ajplung.00258.2005

235. Nowrin K, Sohal SS, Peterson G, Patel R, Walters EH (2014) Epithelial-mesenchymal transition as a fundamental underlying pathogenic process in COPD airways: fibrosis, remodeling and cancer. Expert Rev Respir Med 8(5):547-559. doi:10.1586/ 17476348.2014.948853

236. Albert SP, DiRocco J, Allen GB, Bates JH, Lafollette R, Kubiak BD, Fischer J, Maroney S, Nieman GF (2009) The role of time and pressure on alveolar recruitment. J Appl Physiol (Bethesda, Md : 1985) 106(3):757-765. doi:10.1152/japplphysiol.90735.2008

237. Nieman G, Gatto LA, Marx W, Habashi N (2013) Is time the missing component in protective ventilation strategies? Crit Care Med 41(10):2461-2462. doi:10.1097/CCM.0b013e31828ce91b

238. Retamal J, Bergamini BC, Carvalho AR, Bozza FA, Borzone G, Borges JB, Larsson A, Hedenstierna G, Bugedo G, Bruhn A (2014) Non-lobar atelectasis generates inflammation and structural alveolar injury in the surrounding healthy tissue during mechanical ventilation. Crit Care 18(5):505. doi:10.1186/s13054-0140505-1

239. Zhou Y, Schneider DJ, Morschl E, Song L, Pedroza M, KarmoutyQuintana H, Le T, Sun CX, Blackburn MR (2011) Distinct roles for the A2B adenosine receptor in acute and chronic stages of bleomycin-induced lung injury. J Immunol (Baltimore, Md : 1950) 186(2):1097-1106. doi:10.4049/jimmunol.1002907

240. Suki B, Stamenovic D, Hubmayr R (2011) Lung parenchymal mechanics. Comprehensive Physiology 1(3):1317-1351. doi:10. 1002/cphy.c100033 